2. To: (Receiving Organization)

Distribution

3. From: (Originating Organization) Analytical Services

5. Proj./Prog./Dept./Div.:

6. Cog. Engr.:

P.A. Titzler

LLCE Disposa 1

8. Originator Remarks:

Please review and return comments to me as soon as possible.

ETI-94-0054A

4. Related EDT No.:

7. Purchase Order No.:

$\mathrm{N} / \mathrm{A}$

9. Equip./Component No.:

N/A

10. System/Blog./Facility:

Tank Farms

11. Receiver Remarks:

12. Major Assm. Dwg. No.:

13. Permit/Permit Application No.:

14. Required Response Date:

March 18, 1996

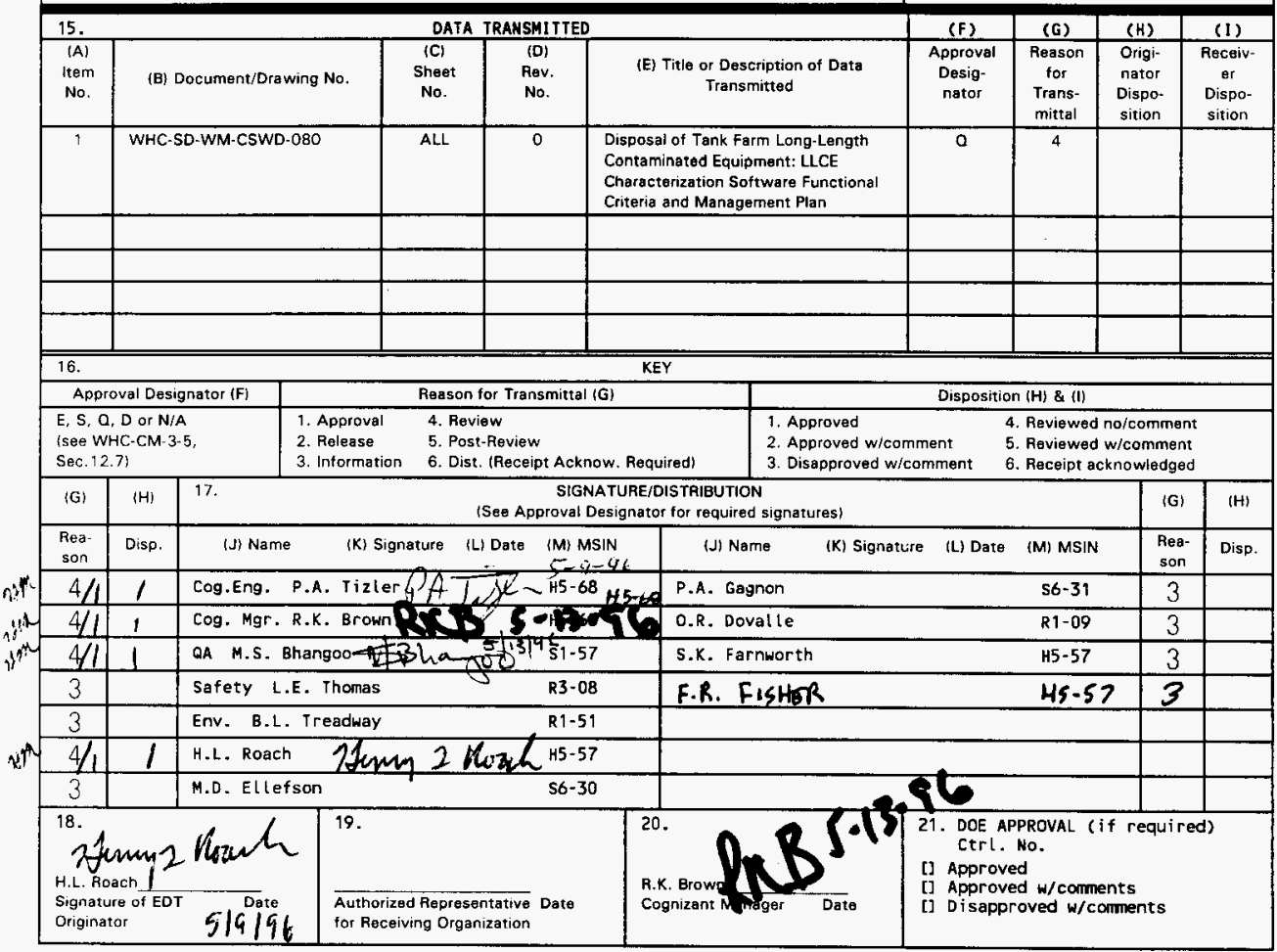

BD-7400-172-2 (04/94) GEF097 


\section{Disposal of Tank Farm Long-Length Contaminated Equipment: LLCE Characterization Software Functional Criteria and Management Plan}

H.L. Roach

ICF-KH. Richland. WA 99352

U.S. Department of Energy Contract DE-AC06-87RL 10930

EDT/ECN: $\quad 603730$

Org Code: 5 A620

UC: 505

B\&R Code: EW3130010

Charge Code: P91K00

Total Pages: 67

Key Words: Characterization, Waste, Radionuclide, Chemical, Disposal. Software. Visual Basic, Access

Abstract:

This plan outlines the functional criteria requirements and the management plan required to develop computer software to calculate the radionuclide and chemical content of the LLCE waste packages. The software will use the calculated radionuclide and chemical content to prepare waste characterization support data in support of LLCE waste characterization and shipment.

TRADEMARK DISCLAIMER. Reference herein to any specific commercial product, process, or service by trade name, trademark, manufacturer, or otherwise, does not necessarily constitute or imply its endorsement, recomendation, or favoring by the United states Government or any agency thereof or its contractors or subcontractors.

Printed in the United States of America. To obtain copies of this document, contact: WHC/BCS Document Control Services, P.O. Box 1970, Mailstop H6-08, Richland WA 99352, Phone (509) 372-2420; Fax (509) 376-4989.
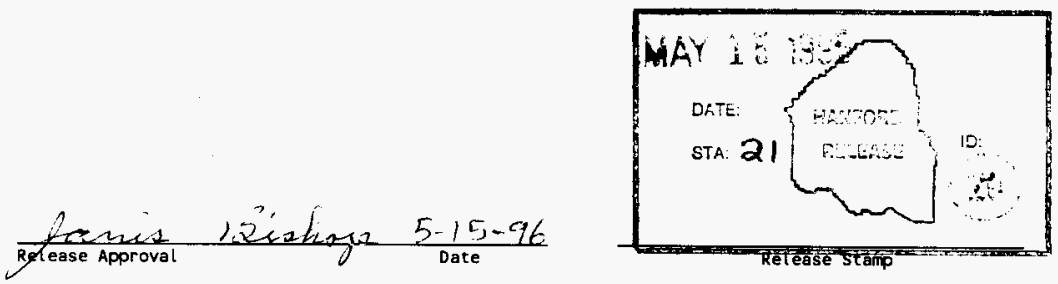

\section{Approved for Public Release}




\section{WHC-SD-WM-CSWD-080 Rev.0}

DISPOSAL OI TANK FARM LONG-LENGTH CONTAMINATED EQUIPMENT:

LLCE CHARACTERIZATION SOFTWARE FUNCTIONAL CRITERIA AND MANAGEMENT PLAN

ETN-94-0054A

February 1996 
WHC-SD-WM-CSWD-080 Rev.0

TABLE OF CONTENTS

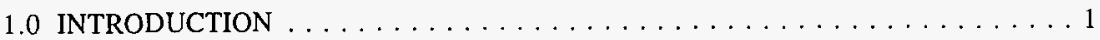

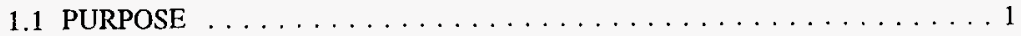

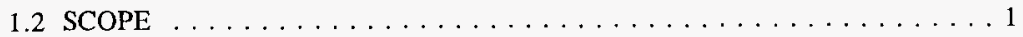

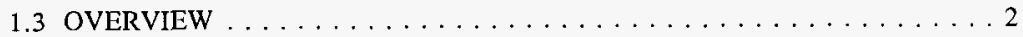

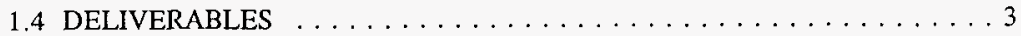

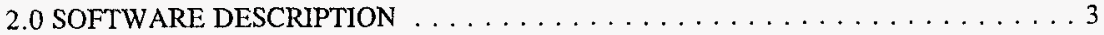

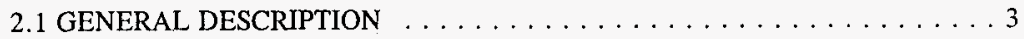

2.2 WASTE CHARACTERIZATION DATABASE PROGRAM $\ldots \ldots \ldots \ldots$

2.2.1 Tank Waste Characterization Data . . . . . . . . . . . . . . 4

2.2.2 LLCE Physical Data and Description . . . . . . . . . . . . . 5

2.2 .3 LLCE Geometry Correction Factors . . . . . . . . . . . . . . . . . . . . . . . .

2.2.4 LLCE Waste Container Data . . . . . . . . . . . . . . 6

2.2 .5 Radionuclide Constant Data . . . . . . . . . . . . . 6

2.2.6 Radionuclide Regulatory Limits Data . . . . . . . . . . . . . . . . . . . . . . . .

2.2.7 Chemical Regulatory Limits Data . . . . . . . . . . . . 7

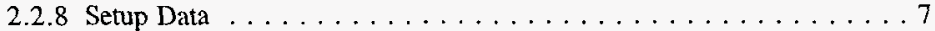

2.2 .9 Audit File Data $\ldots \ldots \ldots \ldots \ldots \ldots \ldots$

2.3 LLCE WASTE CHARACTERIZATION ANALYSIS PROGRAM $\ldots \ldots \ldots 8$

2.3.1 FRRDS Data Interface $\ldots \ldots \ldots \ldots \ldots \ldots \ldots$

2.3.2 FRRDS Gamma Assay Data File Analysis . . . . . . . . . . . . . 10

2.3.3 Radionuclide/Chemical Content and Characterization Support Data . 10

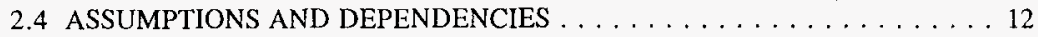

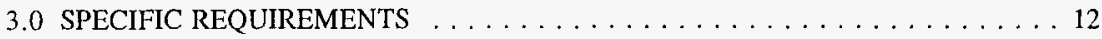

3.1 FUNCTIONAL REQUIREMENTS $\ldots \ldots \ldots \ldots \ldots \ldots \ldots \ldots \ldots \ldots 12$

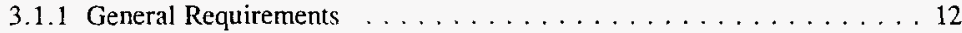

3.1.2 LLCE Characterization Database Program . . . . . . . . . 13

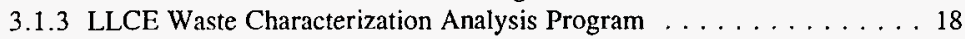

3.2 EXTERNAL INTERFACE REQUIREMENTS $\ldots \ldots \ldots \ldots \ldots \ldots \ldots 21$

3.2 .1 User Interfaces . . . . . . . . . . . . . . . . . . . 21

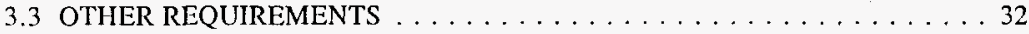

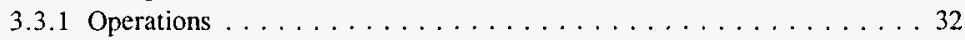

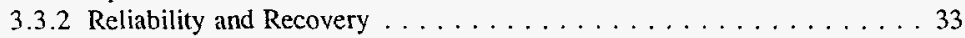

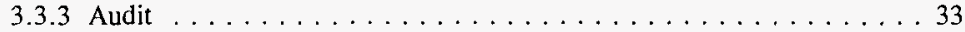

3.3.4 Testing and Acceptance Criteria $\ldots \ldots \ldots \ldots \ldots \ldots \ldots \ldots \ldots$ 


\section{WHC-SD-WM-CSWD-080 Rev.0}

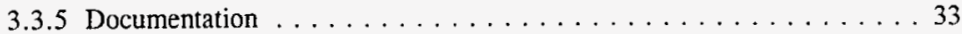

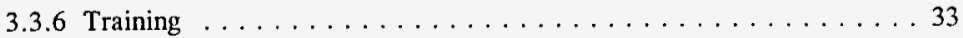

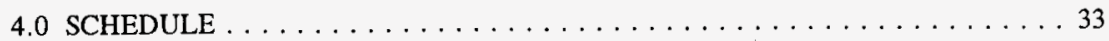

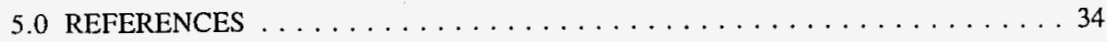

\section{APPENDICES}

Appendix A - Database file description and Structure Appendix B - Description of Existing FRRDS Software Appendix C - FRRDS ASCII Encoded Results File Format Appendix D - Schedule 
WHC-SD-WM-CSWD-080 Rev.0

\section{LIST OF TERMS}

$\begin{array}{ll}\text { CAS } & \text { Chemical Abstract Registry } \\ \text { CFR } & \text { Code of Federal Regulations } \\ \text { CWC } & \text { Central Waste Complex } \\ \text { DOE } & \text { U.S. Department of Energy } \\ \text { DOT } & \text { Department of Transportation } \\ \text { DST } & \text { Double-Shell Tank } \\ \text { EPA } & \text { U.S. Environmental Protection Agency } \\ \text { FRRDS } & \text { Flexible Receiver Radiation Detection System } \\ \text { HPGe } & \text { High Purity Germanium } \\ \text { HRC } & \text { Highway Route Controlled } \\ \text { INEL } & \text { Idaho National Engineering Laboratory } \\ \text { LLCE } & \text { Long-Length Contaminated Equipment } \\ \text { LLMW } & \text { low-level mixed waste } \\ \text { LLW } & \text { Low Level Waste } \\ \text { LSA } & \text { Low Specific Activity } \\ \text { MDI } & \text { Multiple Document Interface } \\ \text { PNL } & \text { Pacific Northwest Laboratory } \\ \text { RCRA } & \text { Resource Conservation and Recovery Act of } 1976 \\ \text { RMW } & \text { Radioactive Mixed Waste } \\ \text { SWSDR } & \text { Solid Waste Storage/Disposal Record } \\ \text { SAR } & \text { Safety Analysis Report } \\ \text { SARP } & \text { Safety Analysis Report for Packaging } \\ \text { SST } & \text { Single-Shell Tank } \\ \text { SWD } & \text { Solid Waste Disposal } \\ \text { TCD } & \text { Tank Characterization Database } \\ \text { TRU } & \text { Transuranic } \\ \text { TRUM } & \text { Transuranic mixed waste } \\ \text { TWINS } & \text { Tank Waste Information Network System } \\ \text { TWRS } & \text { Tank Waste Remediation System } \\ \text { WAC } & \text { Washington State Administrative Code } \\ \text { WDOE } & \text { Washington State Department of Ecology } \\ \text { WHC } & \text { Westinghouse Hanford Company } \\ & \end{array}$




\section{DISPOSAL OF TANK FARM LONG-LENGTH CONTAMINATED EQUIPMENT: LLCE CHARACTERIZATION SOFTWARE FUNCTIONAL CRITERIA AND MANAGEMENT PLAN}

\subsection{INTRODUCTION}

\subsection{PURPOSE}

The purpose of this plan is to develop software that will be used with the Flexible Receiver Radiation Detection System (FRRDS) to provide the radionuclide and chemical inventory of Long Length Contaminated Equipment (LLCE) retrieved from underground waste storage tanks. The LLCE radionuclide/chemical inventory data will be used to generate waste characterization data to support preparation of waste shipping documents.

\subsection{SCOPE}

Two software programs will be developed to provide LLCE waste characterization support. These programs will be written using Microsoft Visual Basic' and will be designed to run on a IBM-AT ${ }^{2}$ compatible computer using the Microsoft Windows ${ }^{3} 3.1$ operating system.

The LLCE Characterization database program will maintain a database of all tank waste characterization data, LLCE physical data, and regulatory data used for LLCE waste characterization. It's purpose will be to prepare a characterization data file for the LLCE being retrieved and to save that information for reuse in subsequent LLCE retrievals. It's primary output will be a data file that will be generated for each LLCE prior to LLCE retrieval. This data file will be required by the LLCE waste characterization analysis program. The program will be designed so that all data in the database can be reviewed and changed as regulations change or more current tank waste data becomes available.

The LLCE waste characterization amalysis program is the second program to be developed. It will calculate the chemical/radionuclide inventory of the LLCE being retrieved. It's three main functions will be as follows:

\footnotetext{
${ }^{1}$ Visual Basic is a trademark of Wilson WindowWare, Inc., Seattle, WA.

${ }^{2}$ IBM-AT is a trademark of the International Business Machines Corporation

${ }^{3}$ Windows is a trademark of Microsoft Corporation
} 


\section{WHC-SD-WM-CSWD-080 Rev.0}

- Interface with the microVAX computer that operates the gamma assay detectors on the FRRDS. This interface is accomplished by the transfer of the FRRDS gamma assay data through a data disk produced by the microVAX control computer.

- Analyze the raw gamma assay data produced by the FRRDS. The total content of all measured gamma radioisotopes will be calculated for the LLCE. These numbers will be corrected for LLCE geometry to produce the final content numbers.

- The measured gamma radioisotopes will be ratioed against the tank waste content data to produce a total radionuclide/chemical inventory estimate for the LLCE. The radionuclide/chemical inventory estimates will be used to generate waste characterization data to support preparation of waste shipping documents.

\subsection{OVERVIEW}

The Long Length Contaminated Equipment (LLCE) disposal effort involves developing a standard process for retrieval, handling, and disposal of LLCE from any one of the 177 underground waste storage tanks, catch tanks, and lift stations. These tanks contain radionuclides and EPA/WDOE RCRA listed wastes. The LLCE in contact with this waste will be characterized as Low Level Waste (LLW), Low Level Mixed Waste (LLMW), or TRU mixed Waste (TRUM) when retrieved dependant on the success of the water rinse and the content of the waste tank.

When LLCE are retrieved from the tanks every effort is made to remove any residual tank waste that is on the equipment surfaces. It is expected that a small amount (thin layer) of tank waste will remain on the LLCE after retrieval. The radionuclide and chemical content of this residual layer must be assessed to determine the proper waste designation, handling, and disposition requirements for the LLCE.

The flexible receiver assembly was developed as part of project W-151 and will also be used for the standard LLCE disposal process that is currently being developed. The software development, which is the subject of this plan, is in support of this overall standard LLCE disposal process development effort. The flexible receiver assembly performs several functions. It maintains containment of the LLCE during retrieval, allows video inspection of exterior LLCE surfaces after water rinse, and performs a gamma assay of the LLCE as it's being retrieved. The FRRDS is a subsystem of the flexible receiver assembly which provides the gamma assay function.

Disposal of Tank Farm Long-Length Contaminated Equipment: Radiological and Chemical Characterization Plan, WHC-SD-WM-TCP-007, was written to document how the 


\section{WHC-SD-WM-CSWD-080 Rev.0}

FRRDS generated gamma assay data will be used to determine the radionuclide/chemical content of the LLCE. In addition this plan contains procedures for determining the waste designation and support information for a LLCE waste package. This software development will develop computer programs that will implement the LLCE waste characterization procedures in the radionuclide and chemical characterization plan.

\subsection{DELIVERABLES}

The following shall be developed and will be completed by 9/30/96.

- $\quad$ LLCE waste characterization database program software and associated databases.

- LLCE waste characterization analysis program software.

- Software acceptance test plan and acceptance test report.

- $\quad$ The user manual for this software will be developed in FY97.

\subsection{SOFTWARE DESCRIPTION}

\subsection{GENERAL DESCRIPTION}

The software developed with this plan will be written in Microsoft Visual Basic and will be Windows 3.1 based applications. User input will be made in on-screen forms and dialog boxes. Every attempt will be made to make these programs as user friendly as possible.

One purpose of having two separate programs to perform the LLCE waste characterization function is to allow for control of data. It is anticipated that only authorized personnel will be assigned the responsibility to use the LLCE characterization database program and to generate the characterization data file required by the LLCE waste characterization analysis program. The LLCE waste characterization analysis program can be used the field when the LLCE is being retrieved. The field user will not be able to change tank waste characterization data without access to the LLCE characterization database program. 
WHC-SD-WM-CSWD-080 Rev.0

\subsection{WASTE CHARACTERIZATION DATABASE PROGRAM}

The databases maintained by the LLCE characterization database program will be in Microsoft ${ }^{4}$ Access 2.0 format. This data will be directly accessed and managed by the LLCE characterization database program. Description and structure of the databases is documented in Appendix A.

This program will maintain databases of variable data that is used to perform waste designation and characterization of the LLCE. Much of the data in this database will not change frequently. It will track tank waste characterization data, LLCE physical data, physical constants, and various regulatory limits. The program will allow the user to view, update data (if required), and to provide hard copy of the database. In addition this program will be used to prepare a characterization data file that is specific for the LLCE and waste tank that the LLCE is retrieved from. This data file will provide data required to the LLCE waste characterization analysis program.

The program will maintain an audit file which will track the use of the program and will record the date any of the databases are changed.

The sections that follow outline the data that will be maintained by the database program.

\subsubsection{Tank Waste Characterization Data}

This will contain the radionuclide/chemical content data for all of the 177 underground waste storage tanks. The initial database will have the most up to date data that can be obtained for the waste tanks. However, given the current state and change in tank waste characterization information, it is essential that this data be reviewed prior to LLCE retrieval and updated if more accurate or current data is available.

Up to ten layers of tank waste may be defined for each tank. Each layer may have a different waste composition. Different units may be used as long as they are consistent for all chemical and radionuclide entries for a tank. If more than one tank waste layer is defined for a tank the user must manually input data for the tank waste content of all layers. In addition the thickness and relative position of each tank waste layer must be defined. If more than one tank waste layer is defined the program user will be prompted to enter the distance from the bottom of the waste tank to the bottom tip of the LLCE. This is necessary to relate the different tank waste layers to the gamma assay data.

\footnotetext{
${ }^{4}$ Microsoft is a trademark of Microsoft Corporation
} 


\section{WHC-SD-WM-CSWD-080 Rev.0}

When there is more than one tank waste layer defined weighted averages will be used to determine the content of the tank waste at each one foot section of the LLCE.

Any data that is changed or added will be saved to the database and will become the default for that waste tank the next time the data is accessed.

\subsubsection{LLCE Physical Data and Description}

Physical data for all currently defined LLCE will be maintained by the program. The user will enter the drawing and part number for the LLCE being retrieved. If the drawing number is recognized the program will retrieve the current description, overall diameter, length, required waste container size, and weight of LLCE from the database. If the LLCE drawing number is not recognized the program will ask the user to enter physical data for the new LLCE. Physical data may be edited and changed as necessary.

Any data that is changed or added will be saved to the database and will become the default for the LLCE the next time the data is accessed.

\subsubsection{LLCE Geometry Correction Factors}

These factors must be calculated for a LLCE the first time the LLCE is retrieved. The Nuclear Physics and Shielding group is responsible for preforming this required analysis. The waste generator is responsible to contract with the Nuclear Physics and Shielding group to conduct this analysis. Very few LLCE have been analyzed to determine their geometry correction factors. These few LLCE will have the geometry correction factors predefined at the time of initial database creation. For all other LLCE, the Default correction factors will be 1.0 unless changed by the user. However, using the default (1.0) correction factors will result in inaccurate radionuclide content estimates.

The geometry correction factors will be calculated for one foot increments along the length of the LLCE. A different factor will be determined for each measured gamma isotope for each one foot increment of length.

The Nuclear Physics and Shielding group may be able relate previous calculations to new LLCE if the new LLCE is very similar in geometry to LLCE previously analyzed. It will be their responsibility to make this call. At least 2 to 3 months prior to LLCE retrieval should be allowed for the Nuclear Physic and Shielding group to complete this analysis.

Any data that is changed or added will be saved to the database and will become the default for the LLCE the next time the data is accessed. 


\section{WHC-SD-WM-CSWD-080 Rev.0}

\subsubsection{LLCE Waste Container Data}

This data will not change unless changes are made to the design of the waste containers. Physical data for the nine (9) LLCE waste containers will be predefined in the database. This will include Container OD, ID, length, maximum allowable LLCE length, maximum allowable LLCE diameter, tare weight, drawing number(s), internal volume, external volume, skid drawing number(s), and skid weight.

The program will automatically select the proper waste container size based on the LLCE selected for retrieval. However, the program user will be able to override this selection if another container size will be used for some reason.

Although this data will rarely change (if ever), the user will be allowed to view, edit, and produce hard copy of the data. Any data that is changed will be saved to the database and will become the default the next time the data is accessed.

\subsubsection{Radionuclide Constant Data}

This data will not generally change unless a new radionuclide needs to be added to the list. However, all data can be reviewed, edited, and hard copy of the database may be made if necessary. The following data will be tracked for each radionuclide:

- $\quad$ Radionuclide atomic weight and element name

- $\quad$ Radionuclide specific activity

- Radionuclide half life

- Daughter isotopes and branching ratios

- Radioactive emission type : alpha, beta, gamma or x-ray

- If the radionuclide is fissile or TRU isotope

- Radionuclide heat generation $(\mathrm{W} / \mathrm{Ci})$

\subsubsection{Radionuclide Regulatory Limits Data}

This data will not generally change unless there is a change in regulatory limits. However, all data can be reviewed, edited, and hard copy of the database may be made if necessary. The following data will be tracked for each radionuclide: 
WHC-SD-WM-CSWD-080 Rev.0

- Radionuclide atomic weight and element name

- Category $1 \mathrm{LLW}$ limit (Ci/m3)

- Category 3 LLW limit (Ci/m3)

- $\quad$ NRC Class $\mathrm{C}$ limit $(\mathrm{Ci} / \mathrm{m} 3)$

- Category 3 , noncombustible waste limit $(\mathrm{Ci} / \mathrm{m} 3)$

- PE-Ci correction factor for TRU waste

- $\quad$ Pu-239 FGE correction factor for TRU waste

- DOT A2 limit curies

- WHC-EP-0063-4 A2 limit curies

- $\quad$ CWC Curie limit per waste package

- $\quad$ DE-Ci factor $(\mathrm{Ci} / \mathrm{Ci})$

- $\quad$ Current SARP limit in curies

- DOE/NRC 741 reporting unit (grams)

\subsubsection{Chemical Regulatory Limits Data}

This data will track the D004-D011 waste code limits. The D004-D011 waste code limits are the $\mathrm{mg} / \mathrm{L}$ limits for heavy metals. These limits are specified in the current WAC 173-303-090(8)(C). If the waste concentration for these heavy metals exceeds the established limits then the LLCE waste will be characterized with the applicable ' $D$ ' waste code. These code limits can be changed if necessary.

\subsubsection{Setup Data}

This data will contain the list of valid measurable gamma isotopes. The list of valid measurable gamma isotopes is the list of gamma isotopes that will be considered valid when evaluating the FRRDS gamma assay data. This list of gamma isotopes can be changed if 


\section{WHC-SD-WM-CSWD-080 Rev.0}

necessary. Isotopes can be added or deleted. A hard copy report of this data can be produced.

\subsubsection{Audit File Data}

This data will provide an audit trail on the use of the characterization database program. It will maintained automatically by the program and will contain the following information:

- Program user name

- Date of program use

- Characterization data file name

- LLCE Description, LLCE Drawing and part number

- Tank and tank riser LLCE retrieved from

- Last revision date for databases: TANKCHAR.DB, LLCEPHYS.DB, LLCEGEOM.DB, LLCECONT.DB, LLCENUC.DB, RADREG.DB, CHEMREG.DB, and LLCESET.DB

\subsection{LLCE WASTE CHARACTERIZATION ANALYSIS PROGRAM}

The LLCE waste characterization analysis program will be a windows based program written in Microsoft Visual Basic. All user entry will be made in on screen forms and dialog boxes. This program can be used in the field at the time the LLCE is retrieved or in the office after LLCE retrieval. Incomplete (missing data) entry of data forms will be permitted. All data input up to the time of normal program exit will be saved. Successful data analysis will not be possible until all required data have been input. The program will notify the program user if data is missing and the user attempts to do characterization analysis with incomplete data. During the normal startup of the LLCE characterization analysis program, the program user will be asked if this program run is for an existing or new LLCE retrieval. With an existing LLCE retrieval all data saved for the previous program run will be retrieved and the data entry forms will be filled with the existing data. At this point the user can complete data entry or change previous data entry and rerun the analysis of the LLCE. Selecting new analysis is for new LLCE retrievals (all forms are blank). The program user must enter a name for any new LLCE retrieval. This name will be used to create a file to store all user input data. 


\section{WHC-SD-WM-CSWD-080 Rev.0}

Two external data files are required by this program. The characterization data file generated by the LLCE characterization database program must be specified. The other data file required is the raw gamma assay data file generated by the FRRDS. A windows based file dialog box will simplify the task of specifying the file name and path for these files.

The program will require the program user to specify the LLCE being retrieved by drawing number and part number, the tark and tank number for the tank the LLCE is being retrieved from, and the riser number the LLCE is being removed from. This information will be used to verify that the LLCE characterization data file is correct for this LLCE retrieval. The program user will be required, at the time of LLCE retrieval, to enter the crane position (ft) at the time the LLCE riser flange is visible using the video system for the flexible receiver internal view window. This will relate the arbitrary crane position reading to actual position or location on the LLCE. In addition the program user will be required to input weight data for the LLCE and the flexible receiver bag and lifting dunnage. After this input is complete LLCE waste characterization analysis can be completed.

The following sections describes the three main functions of the LLCE waste characterization analysis program.

\subsubsection{FRRDS Data Interface}

The interface from the FRRDS system will be in the form of a ASCII encoded data file recorded on a MSDOS ${ }^{5}$ formatted disk. This file will be transferred from the FRRDS microVAX control computer onto a floppy disk and that disk will be physically placed into a disk drive in the computer system running the LLCE characterization analysis software. The format of the data file is documented in Appendix C. A description of the FRRDS provided software and software function is documented in Appendix B.

The gamma assay data file will contain multipie gamma inventory results for the LLCE. The FRRDS system acquires a spectrum for the LLCE at approximately one minute intervals. Since the LLCE is retrieved at one foot per minute this spectrum will cover an approximate one foot section of the LLCE. If the LLCE is re-luwered for re-rinsing during retrieval subsequent gamma inventory records may supersede prior inventory records and must be accounted for by the software. Position tracking for the inventory records is possible since each record is stamped with the current crane position in feet. At each position where data is acquired, data is acquired from each of the three independent detectors. Total gamma isotope inventory for that section of the LLCE must be interpreted from the readings of the three detectors. If the surface dose rate of the LLCE becomes excessive one or more of the

\footnotetext{
${ }^{5} \mathrm{MSDOS}$ is a trademark of the Microsoft Corporation
} 


\section{WHC-SD-WM-CSWD-080 Rev.0}

detectors will become saturated and no record will be generated by those detectors while they are non-functional. If All detectors are non-functional gamma assay data will be missing for that section of the LLCE.

Some of the gamma radionuclides reported in the data file will be phantoms or ghosts that will have some reported activity but in reality are non-existent. The list of valid measured gamma radionuclides will be maintained by the LLCE characterization database program. All other measured radionuclides will be ignored.

Once the LLCE is retrieved an existing microVAX program "AVR2" must be tun on the FRRDS microVAX control computer. This program generates the ASCII encoded gamma assay data file that is read by the LLCE waste characterization analysis program.

\subsubsection{FRRDS Gamma Assay Data File Analysis}

The first main analysis function performed by the program, after successful data input, is to analyze the raw FRRDS generated data to estimate the total measured gamma isotope content of the LLCE waste. The first step is to reconcile all of the multiple and conflicting one foot length gamma inventory records to determine the measured gamma isotope content for each one foot segment of the LLCE. Next geometry correction factors are applied to the measured gamma isotope content for each one foot section of the LLCE. Once the geometry correction factors have been applied the total measured gamma isotope inventory for the LLCE can be calculated.

Where multiple tank waste layers are defined the total measured gamma isotope content will be calculated for each section of the LLCE in the different tank waste layers.

If the surface dose rate of the LLCE becomes excessive the FRRDS will not produce gamma assay data for these areas. When the program detects this condition the program user is notified of the problem and is told which sections of the LLCE is missing gamma assay data. It will be the program users responsibility to determine by other means what the gamma content estimates should be for these areas. The program will prompt the program user to manually enter the missing inventory data.

\subsubsection{Radionuclide/Chemical Content and Characterization Support Data}

The characterization analysis program will use the total measured gamma isotope content estimates along with the tank waste characterization data to calculate the total radionuclide and chemical data inventory for the LLCE that is retrieved. In addition the program will calculate characterization support data in accordance with the procedures in Disposal of Tank Farm Long-Length Contaminated Equipment: Radiological and Chemical Characterization Plan, 


\section{WHC-SD-WM-CSWD-080 Rev.0}

WHC-SD-WM-TCP-007. The LLCE waste characterization analysis program will calculate the following data to support preparation of shipping papers for the LLCE waste:

- Estimate of total radionuclide content for LLCE waste package

- Estimate of total Chemical content for LLCE waste package

- Sum of fractions for Category $1 \mathrm{LLW}$

- Sum of fractions for Category $3 \mathrm{LLW}$

- Sum of fractions for NRC Class C

- Sum of fractions for TRU

- Flag if the TRU fraction exceeds the established suspect TRU limit or regulatory TRU limit of $100 \mathrm{nCi} / \mathrm{g}$

- Waste category based on radionuclide content and sum(s) of fractions

- Calculate Plutonium Equivalent Curie (PE-Ci) (for TRU)

- $\quad$ Flag if PE-Ci exceeds 35 PE-Ci limit for TRU waste

- Calculate Pu-239 Fissile Gram Equivalent (FGE)for TRU waste

- Calculate total alpha curies for waste package for TRU waste

- Determine if waste package contains accountable materials

- Determine the heat generation rate for the waste package

- Flag if waste package heat generation rate exceeds $3.5 \mathrm{~W} / \mathrm{m}^{3}\left(0.1 \mathrm{~W} / \mathrm{ft}^{3}\right)$

- Determine transportation category (LSA, Limited Quantity, Type-A, Type-B, HRC) according to DOT A2 limits

- Determine transportation category according to A2 values limits in WHC-EP0063-4, Appendix L 
WHC-SD-WM-CSWD-080 Rev.0

- Determine if any CWC curie limits in WHC-EP-0063-4, Appendix L, for waste package are exceeded

- Calculate CWC Dose Equivalent Curie (DE-Ci), if WHC-EP-0063-4, Appendix L, calculated transportation Category $>\mathrm{A}$ or CWC curie limits in WHC-EP-0063-4, Appendix L, are exceeded

- $\quad$ Flag if criticality safety analysis required $\left({ }^{235} \mathrm{U}>15 \mathrm{~g}\right)$

- Determine if any limits established for the LLCE waste package SARP has been exceeded

- Generate summary of recommended hazardous waste codes for waste package

The program user will be able to print a summary report or detailed reports for all the calculations made by the program.

\subsection{ASSUMPTIONS AND DEPENDENCIES}

An assumption must be made that the FRRDS system is fully operational prior to an LLCE retrieval. The FRRDS is an independent system that provide data necessary for LLCE waste characterization. The LLCE waste characterization software is dependent on this proper operation of this system.

These programs will be designed to be run on any IBM-PC compatible running the Windows 3.1 operating system. It is assumed that this $\mathrm{PC}$ will have a minimum of 8 megabytes of ram and at least 50 megabytes of free disk space to accommodate the program files and data files required by these programs.

\subsection{SPECIFIC REQUIREMENTS}

\subsection{FUNCTIONAL REQUIREMENTS}

This section describes the functional requirements for the software that will be developed according to this plan.

\subsubsection{General Requirements}

3.1.1.1 The programs will be a Windows 3.1 based programs capable of running on any IBM-AT compatible that uses the Windows 3.1 operating system, has 8 megabytes total ram and 50 megabyte of free disk space. 


\section{WHC-SD-WM-CSWD-080 Rev.0}

3.1.1.2 Data entry will be by Windows based on screen forms and dialog boxes.

3.1.1.3 Standard Windows File Open, Save, and Print, dialog boxes will be used with this program.

3.1.1.4 Error checking will be conducted by the program. The following ways will be used to implement error checking:

- Where a valid range exists for a data entry point the user input will be checked against this range.

- Data input will be checked for proper format. For example where numbers are expected only numbers will be allowed.

- Lists will be presented to the user for the entry of some data. For example the program will have the user select from a list of valid tank farms ( A, $\mathrm{AX}, \mathrm{AP}, \mathrm{etc})$ to select the tank farm. In turn once the tank farm is selected the user will select from a list of valid tank numbers for that farm to specify which tank in the farm the LLCE is being retrieved from.

- Subroutines in program will have error handling routines to handle expected errors. Message boxes will inform the user when an error has occurred and will provide error recovery information. This information will also be recorded in a text error report file.

3.1.1.5 Program selections that are inappropriate at different points in the program will be greyed out (disabled) or invisible to the user.

3.1.1.6 All Data entered or changed by the user will be saved to a file name selected by the program user.

3.1.1.7 Hard copy reports of all input data and analysis results can be produced.

\subsubsection{LLCE Characterization Database Program}

3.1.2.1 This program will maintain a database of all data required for the characterization of all LLCE. The data that will be tracked is defined in section 2.2 of this plan. This includes tank waste characterization data, LLCE physical data, LLCE geometry correction factors, and regulatory limits and physical constants for radionuclides and chemicals. 


\section{WHC-SD-WM-CSWD-080 Rev.0}

3.1.2.2 The program will be designed to take the program user step by step through the process of generating the characterization database file. However, the program user will not be constrained to follow this program order.

3.1.2.3 The program will produce a data file that contains the tank waste characterization data, LLCE physical data, LLCE geometry correction factors, and LLCE waste container data that is specific for the LLCE that is identified for retrieval and to the waste tank the LLCE is being retrieved from. Physical constants and regulatory limit data is also part of this data file but is not specific to any individual LLCE. This data file is required by the LLCE waste characterization analysis program.

3.1.2.4 For the tank waste characterization data:

- Up to 10 different waste layers can be defined. All layers may have a different waste composition.

- Multiple tank waste layers shall be defined starting from the bottom most layer in the waste tank. Waste layer specific gravity (SpG) and thickness shall be defined for each layer.

- The list of different radionuclides and chemicals in the database is derived from the list of radionuclides and chemicals that exist in the current Tank Waste Information Network System (TWINS) Tank Waste Characterization Database (TCD). Radionuclides or chemicals in the database can be added or deleted from the database. The user will be asked to define all of the properties for the new radionuclide or chemical. Units must be consistent for entering tank waste content data for a tank.

- All existing data can be reviewed, edited, and hard copy reports may be made of the database. If data is added or changed in the database the audit file will note that the date the database was changed.

- Units for entry of radionuclide content data may be in total curie content (i.e. $\mathrm{Ci}$ ), curie content per unit volume (i.e. $\mathrm{Ci} / \mathrm{m}^{3}$ ), or curie content per unit mass(i.e. Ci/g). Unit volume can be in $\mathrm{m}^{3}$ or $\mathrm{cm}^{3}$. Unit mass can be in $\mathrm{kg}$ or grams.

- Units for entry of chemical content data may be in total mass content (i.e. grams), or mass per unit volume (i.e. $\mathrm{g} / \mathrm{L}^{3}$ ). Mass can be in $\mathrm{kg}$ or grams. Volume can be in $\mathrm{m}^{3}, \mathrm{~cm}^{3}$, or liters. 


\section{WHC-SD-WM-CSWD-080 Rev.0}

3.1.2.5 For the LLCE physical data and description data:

- All known LLCE will be predefined in the initial database. There are currently over 581 existing LLCE identified. New LLCE can be entered into the database or existing data can be edited.

- When the program user inputs the drawing and part number for the LLCE being retrieved, the program will check this against the current list of existing LLCE. If it exists in the database the program will automatically bring in the current physical data for the LLCE. If the drawing number is not recognized the program will assume this is a new LLCE and will require the program user to input data for the LLCE. The program will try to check for mistyped drawing numbers. The program user always has the option of printing out the LLCE database to check a hard copy list of current LLCE.

- All data can be reviewed, edited, and hard copy report can be made. Any data that is changed will be saved to the database and will become the default data for the LLCE. If data is added or changed in the database the audit file will note that the date the database was changed.

- If more than one tank waste layer is defined for the LLCE being retrieved, the program user must input distance from the bottom of the waste tank to the bottom most tip of the LLCE.

3.1.2.6 For the LLCE geometry correction factors:

- This will be keyed to the drawing number of the LLCE that the program user has specified for retrieval.

- The geometry correction factors shall be entered for each one foot section of the LLCE starting from the bottom of the LLCE. A geometry correction factor will be entered for each valid gamma radionuclide for each one foot section of the LLCE. Default value will be 1.00 for all valid gamma isotopes unless changed by the program user.

- All data entered will be saved and can be reused the next time that LLCE is specified for retrieval. If data is added or changed in the database the audit file will note that the date the database was changed. 


\section{WHC-SD-WM-CSWD-080 Rev.0}

- All existing LLCE geometry correction factors that have been calculated will be entered into the database at the time of initial database creation.

3.1.2.7 For radionuclide constant data:

- The database will contain the radionuclide constants listed in section 2.2.5 of this plan.

- All data that is changed or added will be saved for reuse of data the next time the program is run.

- All data can be reviewed, edited, and hard copy report can be made.

3.1.2.8 For the radionuclide regulatory limits data:

- The database will contain the radionuclide regulatory limits listed in section 2.2.6 of this plan.

- All data that is changed or added will be saved for reuse of data the next time the program is run. If data is added or changed in the database the audit file will note that the date the database was changed.

- All data can be reviewed, edited, and hard copy report can be made.

3.1.2.9 For the chemical regulatory limits data:

- The database will contain the chemical regulatory limits listed in section 2.2.7 of this plan.

- All data that is changed or added will be saved for reuse of data the next time the program is run. If data is added or changed in the database the audit fite will note that the date the database was changed.

- All data can be reviewed, edited, and hard copy report can be made.

3.1.2.10 For the LLCE waste container data:

- The database will contain the LLCE waste container data listed in section 2.2.4 of this plan 


\section{WHC-SD-WM-CSWD-080 Rev.0}

- The program will automatically retrieve the LLCE waste container data based on the drawing number entered by the program user for the LLCE being retrieved. The program user will be able to override the default container selection if another LLCE container size is used.

- All LLCE container data can be reviewed, edited, and hard copy report can be made. If data is added or clianged in the database the audit file will note that the date the database was changed.

- All data that is changed or added will be saved for reuse of data the next time the program is run.

\subsubsection{For the LLCE setup data:}

- The database will contain the valid measured gamma assay radionuclide list and the suspect TRU limit as described in section 2.2 .8 of this plan

- Data can be added, reviewed, edited, and hard copy report can be made. If data is added or changed in the database the audit file will note that the date the database was changed.

- All data that is changed or added will be saved for reuse of data the next time the program is run.

3.1.2.12 User input to the LLCE characterization database program will be made in the following order:

- At start up of LLCE characterization database program the program user will be prompted to select either a new or existing program run. If existing program run is selected the program user will specify the name of the existing input file. All input data will be input from the existing file into the program. The program user can then change the existing input information and re-create the LLCE characterization data file. If new program run is selected the program user will be prompted to enter a filename that will be used to store user input to the program . A standard Window's file dialog box can be used to assist the program user in selecting the file path and file names.

- The program user will enter the drawing and part number for the LLCE being retrieved and the tank farm and tank number the LLCE is being retrieved from. The program will verify that the numbers are valid. 
- $\quad$ After the LLCE drawing number, tank farm, and tank and tank riser number have been entered the program will present the program user with a logical step by step progression through the program. The program user will not be constrained to follow this program order. The Program user can review, verify, and edit the tank waste characterization data, LLCE physical data, LLCE geometry correction factors, LLCE waste container data, and regulatory limits and physical constants in any order.

- After all data entry is complete and characterization data has been reviewed the LLCE characterization database file can be created.

\subsubsection{LLCE Waste Characterization Analysis Program}

3.1.3.1 This program will calculate the radionuclide and chemical content of an LLCE that is retrieved from anyone of the 177 underground waste storage tanks, catch tanks, and lift stations.

3.1.3.2 User input will be in this order:

- At start up of LLCE waste characterization analysis program the program user will be prompted to either open existing analysis file or to start new analysis.

- Selecting existing analysis will read in data saved from a previous session of the program. All existing data will be retrieved and data entry forms will be filled with existing data. Existing data can be changed or missing data can be entered to allow data analysis to be completed.

- $\quad$ Selecting new analysis will start the program with empty forms. If new analysis is selected the program user will enter a name for the analysis run. This name will be used to create a file to save the data entered during this session.

- With a new analysis, the program user will enter the full path and file name for the LLCE characterization database file created for the LLCE being retrieved. A standard Windows file dialog box can be used to assist the user in supplying this information

- With a new analysis, the program user must enter the full path and file name for the FRRDS generated gamma assay data file created for the LLCE 


\section{WHC-SD-WM-CSWD-080 Rev.0}

during retrieval. A check will be made when the FRRDS data file is read to determine if the last date on in the FRRDS file matches the LLCE pull date entered by the program user. If there is a miss match in dates the program will flag the difference to the program user. The program user will need to determine if the wrong retrieval date or FRRDS file name was specified. A standard Windows file dialog box can be used to assist the user in supplying this information

- The program user will enter the drawing and part number of the LLCE being retrieved and the tank farm ar 1 tank number the LLCE is being retrieved from. The program will verify that the LLCE information entered matches the LLCE data specified in the LLCE characterization database file.

- The program user will enter the tank riser number the LLCE is being retrieved from.

- The program user shall enter the arbitrary crane reading (ft) at the time the LLCE riser flange is visible in the video view window that inspects exterior LLCE surfaces.

- The program user shall enter the weight of the LLCE, lifting dunnage, and flexible receiver bag. The weight of the individual components may be entered separately or the combined weight of all three may be entered. If a crane mounted dynamometer is used the combined weight can be taken from the dynamometer just after the LLCE has been retrieved from the tank and is free hanging on the crane. This assumes that the crane mounted dynamometer has sufficient accuracy.

- The program user shall enter the LLCE retrieval date.

3.1.3.3 The following data will be input to the LLCE waste characterization analysis program by reading a data file generated by the LLCE characterization database program as described in section 3.1 .2 of this plan:

- LLCE drawing and part number, tank farm and tank number defined for the generation of this characterization database file.

- Tank waste characterization data as described in sections 2.2.1 and 3.1.2.4 in this plan. 


\section{WHC-SD-WM-CSWD-080 Rev.0}

- Physical data for the LLCE being retrieved. This will include the data as described in sections 2.2.2 and 3.1.2.5 in this plan.

- LLCE geometry correction factors for the LLCE being retrieved. This will include the data as described in sections 2.2.3 and 3.1.2.6 in this plan.

- LLCE waste container data for the LLCE being retrieved. This will include the data as described in sections 2.2.4 and 3.1.2.7 in this plan.

- Radionuclide physical constants and regulatory limits for all radionuclides present in the tank waste characterization data. This will included the data as described in sections $2.2 .5,2.2 .6,2.2 .8,3.1 .2 .7,3.1 .2 .8,3.1 .2 .9$, and 3.1.2.11 in this plan. Chemical regulatory limits for all chemicals present in the tank waste characterization data as described in 3.1.2.7.

3.1.3.4 The gamma assay data will be input to the LLCE waste characterization analysis program by reading the gamma assay data file generated by the FRRDS for the LLCE that was retrieved as described in section 2.3 .1 of this plan. This data will include the gamma spectrum for each of the three HPGe gamma detectors at each location on the LLCE where the gamma assay spectrum is acquired. The program will check the dates in the FRRDS data file and compare it to the LLCE retrieval date entered by the program user. If there is a mismatch the program user will be notified of the problem. Refer to Appendix $\mathrm{C}$ for a description of this file.

3.1.3.5 Characterization data analysis can be initiated once all user input has been completed as specified in section 3.1.3.2 of this plan.

3.1.3.6 The FRRDS produced gamma assay file content shall be analyzed to produce the estimate for total measured gamma content of the LLCE as specified in section 2.3.2 of this plan.

3.1.3.7 During analysis of the gamma assay data if gamma assay data is missing for a section of the LLCE the program will stop and prompt the user to enter the missing data. Refer to section 2.3.1 and 2.3.2 for a discussion of this problem.

3.1.3.8 The total measured gamma isotope content for the LLCE will be used to estimate the total radionuclide and chemical content of the LLCE as specified in section 2.3.2. This will be accomplished by ratioing the measured gamma radionuclide content to the tank waste content for the tank the LLCE is retrieved from. This procedure is detailed in section 8.1, Disposal of Tank Farm Long-Length Contaminated Equipment: Radiological and Chemical Characterization Plan, 


\section{WHC-SD-WM-CSWD-080 Rev.0}

WHC-SD-WM-TCP-007. If the tank waste characterization data has more than one tank waste layer defined the total radionuclide/chemical content will be summed by tank waste layer.

3.1.3.9 Program status will be given to the program user to help the user determine the current state of the program. Status will be given on a status bar or in a dialog box.

3.1.3.10 The program shall generate hard copy reports for the data input, characterization analysis summary report, and detailed reports for each analysis conducted by the program. The data input report will print out all data input to the program. The summary report will print out the data as specified in section 2.3.2. The detailed reports will print out the tabulated results of the calculations performed in accordance with sections 8.0 and 8.4 in, Disposal of Tank Farm Long-Length Contaminated Equipment: Radiologi al and Chemical Characterization Plan, WHC-SD-WM-TCP-007.

\subsection{EXTERNAL INTERFACE REQUIREMENTS}

\subsubsection{User Interfaces}

\subsubsection{LLCE Characterization Database Program}

The LLCE characterization database program will be a multiple document Interface (MOI) application. There will be a main program window and child windows that open up under the main program window. The following sections describe the windows that will be designed to provide the user interface to the LLCE characterization database program:

\subsection{Main Program Window - All windows will operate within the main program} screen area. When the program starts a dialog box will appear prompting the user to select existing or new file. Selecting new will start the New menu command (see below). Selecting existing will start the Open menu command (described below). The menu bar will contain the main menu bar headings of Eile, Edit,

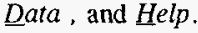

The File menu bar will provide the following commands: 
WHC-SD-WM-CSWD-080 Rev.0

\begin{tabular}{|c|c|}
\hline \multicolumn{2}{|r|}{ File Menu Bar } \\
\hline$\underline{N e w}$ & $\begin{array}{l}\text { This will bring up a file dialog box and will prompt the } \\
\text { program user to enter a path and filename to be used for } \\
\text { storage of user input to the program and for the name of } \\
\text { the file to be used for the LLCE characterization data file. } \\
\text { A new file filename.inp will be created to store user input } \\
\text { to the program. This will also set the name for the LLCE } \\
\text { characterizati. } \mathrm{n} \text { data file as filename.dbf. }\end{array}$ \\
\hline Open & $\begin{array}{l}\text { This will bring up a file dialog box and will prompt the } \\
\text { program user to enter the path and filename for an existing } \\
\text { (old) program run. This will read in the filename.inp file } \\
\text { and will restore user input from this file. The LLCE } \\
\text { characterization data file name will be set as filename.dbf. }\end{array}$ \\
\hline Save & This save the current user input to the file filename. inp. \\
\hline Print & $\begin{array}{l}\text { This will allow the user to print hard copy reports that } \\
\text { relate to the selected tank farm, tank number, and LLCE } \\
\text { being retrieved. The print option is valid only when one of } \\
\text { the data menu windows is opened (described below). } \\
\text { Information that will be included in all data reports is the } \\
\text { current time, date, program user name(s), LLCE selected, } \\
\text { tank farm and tank number selected. The user will also } \\
\text { have the option to select printer and setup printer. }\end{array}$ \\
\hline Exit & $\begin{array}{l}\text { This will exit the program. If any input has changed the } \\
\text { user will be prompted to save data, discard data, or cancel } \\
\text { exit. }\end{array}$ \\
\hline
\end{tabular}

The Edit menu bar will provide the following commands:

\begin{tabular}{|c|l|}
\hline \multicolumn{2}{|c|}{ Edit Menu Bar } \\
\hline Cut & $\begin{array}{l}\text { This will allow the user to select text using the mouse and } \\
\text { to cut that text to the windows clipboard. }\end{array}$ \\
\hline Copy & $\begin{array}{l}\text { This will allow the user to select text using the mouse and } \\
\text { to copy that text to the windows clipboard. }\end{array}$ \\
\hline Paste & $\begin{array}{l}\text { This will allow text be pasted from the windows clipboard } \\
\text { to the current cursor position. }\end{array}$ \\
\hline
\end{tabular}




\section{WHC-SD-WM-CSWD-080 Rev.0}

The Data menu bar will provide the following commands:

\begin{tabular}{|c|c|}
\hline \multicolumn{2}{|r|}{ Data Menu Bar } \\
\hline LLCE Select & $\begin{array}{l}\text { This will open the LLCE select window to select LLCE } \\
\text { part and drawing number, tank farm, and tank number. } \\
\text { Also the program user name(s) is input in this window. } \\
\text { All other selections in the Data menu bar is disabled } \\
\text { until this information is entered. }\end{array}$ \\
\hline LLCE Physical & $\begin{array}{l}\text { This will open the LLCE physical data window for the } \\
\text { selected LLCE for review and editing. }\end{array}$ \\
\hline Tank Waste & $\begin{array}{l}\text { This will open the tank waste characterization data } \\
\text { window for the selected tank farm and waste tank for } \\
\text { review and editing. }\end{array}$ \\
\hline LLCE Geometry & $\begin{array}{l}\text { This will open the LLCE geometry correction factors } \\
\text { window for the selected LLCE for review and editing. }\end{array}$ \\
\hline Container & $\begin{array}{l}\text { This will open the LLCE waste container data window } \\
\text { for the selected LLCE for review and editing. }\end{array}$ \\
\hline Radionuclide & $\begin{array}{l}\text { This will open the radionuclide constants data window } \\
\text { for review and editing. }\end{array}$ \\
\hline Rad Reg & $\begin{array}{l}\text { This will open the radionuclide regulatory limits } \\
\text { windows for review and editing. }\end{array}$ \\
\hline Chem Reg & $\begin{array}{l}\text { This will open the chemical regulatory limits windows } \\
\text { for review and editing. }\end{array}$ \\
\hline Setup & This will open the setup window for review and editing. \\
\hline Make $D B$ & $\begin{array}{l}\text { This will open a dialog box which will allow the } \\
\text { program user to write the LLCE characterization } \\
\text { database file for the selected LLCE or cancel. If write } \\
\text { is selected this will write out the LLCE waste } \\
\text { characterization database file : filename. dbf. }\end{array}$ \\
\hline
\end{tabular}

The $\underline{H}$ elp menu bar will provide the following menu commands menu commands:

\begin{tabular}{|l|l|}
\hline \multicolumn{2}{|c|}{ Help Menu Bar } \\
\hline Contents & Will display a help screen for the program commands. \\
\hline
\end{tabular}


WHC-SD-WM-CSWD-080 Rev.0

\begin{tabular}{|l|l|}
\hline \multicolumn{2}{|c|}{$\underline{\text { Help Menu Bar }}$} \\
\hline$\underline{\text { Abbout }}$ & Will display program version information. \\
\hline
\end{tabular}

3.2.1.1.2 LLCE Select Window - This window is opened when the menu command $L L C E$ Select is selected. This window is where the part and drawing number for the LLCE, tank farm and tank number, and program user information is entered. All menu bar selections under the Data menu bar, except for LLCE select, is disabled until this window input is completed. To exit this window the program user can select next or ok. If the user selects next this automatically opens the LLCE physical data window. Selecting ok takes the user back to the main window. Selecting $\underline{\text { Print }}$ from the File menu will allow the user to print the information in this window.

3.2.1.1.3 LLCE Physical Data Window - This window is opened when the menu command LLCE Physical is selected. This brings up the LLCE physical data window for the selected LLCE. The user can review and edit the data as required. To exit this window the program user can select next or ok. If the user selects next this automatically opens the tank waste characterization data window. Selecting ok takes the user back to the main window. Selecting Print from the Eile menu will allow the user to print the information for the selected LLCE or optionally information for all LLCE.

3.2.1.1.4 Tank Waste Characterization Data Window - This window is opened when the menu command Tank Waste is selected. This brings up the current tank waste characterization data for the selected waste tank. This allow the program user to review the existing tank waste characterization data and to edit the data according to section 2.2 .1 of this plan. If multiple tank waste layers are defined the distance from the bottom of the tank to the tip of the LLCE must be entered here. To exit this window the program user can select next or ok. If the user selects next this automatically opens the LLCE geometry correction factors window. Selecting ok takes the user back to the main window. Selecting Print from the Eile menu will allow the user to print the tank waste characterization data for the selected tank.

3.2.1.1.5 LLCE Geometry Correction Factors Window - This window is opened when the menu command $L L C E$ Geometry is selected. This window allows for entry of the LLCE geometry correction factors described in section 2.2.3 of this plan. To exit this window the program user can select next or ok. If the user selects next this automatically opens the LLCE waste container data window. Selecting ok will open takes the user back to the main window. Selecting Print from the File 
menu will allow the user to print the LLCE geometry correction factors for the selected LLCE.

3.2.1.1.5 LLCE Waste Container Data Window - This window is opened when the menu command Container is selected. This window allows the program user to review and change the LLCE waste container size and waste container data (if necessary)in accordance with section 2.2.4 of this plan. To exit this window the program user can select next or ok. If the user selects next this automatically opens the radionuclide constants data window. Selecting ok takes the user back to the main window. Selecting Print from the Eile menu will allow the user to print the LLCE waste container data for the selected LLCE or for all LLCE waste containers.

3.2.1.1.6 Radionuclides Constants Data Window - This window is opened when the menu command Radionulide is selected. This window allows the program user to review and edit radionuclide physical constants data in accordance with section 2.2.5 of this plan. To exit this window the program user can select next or ok. If the user selects next this automatically opens the radionuclide regulatory limits data window. Selecting ok takes the user back to the main window. Selecting Print from the Eile menu will allow the user to print the radionuclide constant data currently in the database.

3.2.1.1.6 Radionuclide Regulatory Limits Data Window - This window is opened when the program user selects the menu command Rad Reg. This window allows the program user to review and edit the regulatory limits for radionuclides in accordance with section 2.2 .6 of this plan. To exit this window the program user can select next or ok. If the user selects next this automatically opens the chemical regulatory limits data window. Selecting ok takes the user back to the main window. Selecting Print from the File menu will allow the user to print the radionuclide regulatory data currently in the database.

3.2.1.1.7 Chemical Regulatory Limits Data Window - This window is opened when the program user selects the menu command Chem Reg. This window allows the program user to review and edit the regulatory limits for chemicals in accordance with section 2.2 .7 of this plan. To exit this window the program user can select next or ok. If the user selects next this automatically opens the setup data window. Selecting ok takes the user back to the main window. Selecting $\underline{\text { Print }}$ from the File menu will allow the user to print the radionuclide regulatory data currently in the database. 
3.2.1.1.7 Setup Data Window - This window is opened when the program user selects the menu command Setup. This window allows the program user to edit the list of valid gamma radionuclides. The valid gamma radionuclice list is discussed in section 2.3.1 of this plan. To exit this window the program user can select next or ok. If the user selects next this automatically opens the Write Database dialog box (Make $D B$ menu command). If all required user input is complete the LLCE characterization database file filename. $d b f$ can be written. Selecting ok takes the user back to the main window. Selecting $\underline{\text { Print }}$ from the Eile menu will allow the user to print the setup data currently in the database. To exit this window the program user selects ok.

\subsubsection{LLCE Waste Characterization Analysis Program}

The LLCE waste characterization analysis program will also be a MDI application. There will be a main program window and child windows that open up under the main program window. The following sections describe the windows that will be designed to provide the user interface to the program:

3.2.1.2.1 Main Program Window - All windows will operate within the main program screen area. The menu bar will contain the menu bar headings of File, Edit, Data, and $\underline{H}$ elp. When the program starts a dialog box will be displayed prompting the user to select existing analysis or new analysis. Selecting new will start the New menu command (see below). Selecting existing will start the Open menu command (see below).

The File menu bar will provide the following commands:

\begin{tabular}{|c|l|}
\hline \multicolumn{2}{|c|}{ Eile Menu Bar } \\
\hline New & $\begin{array}{l}\text { This will bring up a file dialog box and will prompt the } \\
\text { program user to enter a path and filename to be used for } \\
\text { storage of user input. New file filename.anl will be created } \\
\text { to store user input to the program. }\end{array}$ \\
\hline Open & $\begin{array}{l}\text { This will bring up a file dialog box and will prompt the } \\
\text { program user to enter the path and filename for an existing } \\
\text { (old) program run. This will read in the filename.anl file } \\
\text { and will restore user input from this file. }\end{array}$ \\
\hline$\underline{\text { Save }}$ & This save the current user input to the file filename.anl. \\
\hline
\end{tabular}


WHC-SD-WM-CSWD-080 Rev.0

\begin{tabular}{|c|l|}
\hline \multicolumn{2}{|c|}{ Eile Menu Bar } \\
\hline Print & $\begin{array}{l}\text { This will allow the user to print hard copy report of user } \\
\text { input and program analysis output. The print option will } \\
\text { bring up a print window that will allow the user to select } \\
\text { which reports to print. }\end{array}$ \\
\hline Exit & $\begin{array}{l}\text { This will exit the program. If any input has changed the } \\
\text { user will be prompted to save data, discard data, or cancel } \\
\text { exit. }\end{array}$ \\
\hline
\end{tabular}

The Edit menu bar will provide the following commands:

\begin{tabular}{|c|l|}
\hline Cut & $\begin{array}{l}\text { Edit Menu Bar } \\
\text { This will allow the user to select text using the mouse and } \\
\text { to cut that text to the windows clipboard. }\end{array}$ \\
\hline Copy & $\begin{array}{l}\text { This will allow the user to select text using the mouse and } \\
\text { to copy that text to the windows clipboard. }\end{array}$ \\
\hline Paste & $\begin{array}{l}\text { This will allow text be pasted from the windows clipboard } \\
\text { to the current cursor position. }\end{array}$ \\
\hline
\end{tabular}

The Data menu bar will provide the following commands:

\begin{tabular}{|l|l|}
\hline \multicolumn{1}{|c|}{ Data Menu Bar } \\
\hline LLCE Select & $\begin{array}{l}\text { This will open the LLCE select window to select LLCE } \\
\text { part and drawing number, tank farm, tank number, and } \\
\text { tank riser number. In addition the program user name(s) } \\
\text { can be entered. After the LLCE is selected the file path } \\
\text { and name for the LLCE characterization data file and } \\
\text { FRRDS gamma assay data file is entered and verified in } \\
\text { this window. }\end{array}$ \\
\hline Field Data & $\begin{array}{l}\text { This will open the field data window for the entry of } \\
\text { field data. }\end{array}$ \\
\hline
\end{tabular}




\section{WHC-SD-WM-CSWD-080 Rev.0}

\begin{tabular}{|c|l|}
\hline \multicolumn{2}{|c|}{ Data Menu Bar } \\
\hline Add Data & $\begin{array}{l}\text { This will open the add missing data window for adding } \\
\text { missing gamma assay data. This menu selection will be } \\
\text { disabled normally. It will become active if during an } \\
\text { analysis run (Calculate menu command) gamma assay } \\
\text { data is found to be missing in the FRRDS gamma assay } \\
\text { data file. }\end{array}$ \\
\hline Calculate & $\begin{array}{l}\text { This will open the LLCE calculate dialog box. This } \\
\text { dialog boxes starts characterization analysis and provides } \\
\text { status of analysis run. }\end{array}$ \\
\hline
\end{tabular}

The Help menu bar will provide the following menu commands menu commands:

\begin{tabular}{|c|l|}
\hline \multicolumn{2}{|c|}{ Help Menu Bar } \\
\hline Contents & Will display a help screen for the program commands. \\
\hline About & Will display program version information. \\
\hline
\end{tabular}

3.2.1.2.2 LLCE select window - This window is opened when the program user selects the $\underline{L L C E}$ Select menu command. The user shall input the LLCE drawing and part number, tank farm, tank number, LLCE retrieval date, and tank riser that the LLCE is being retrieved from. In addition the program will ask for the program user(s) name and for the package PIN number (if available).

After the LLCE drawing number, tank farm, and tank number has been entered, areas in this window will become active which will require the program user to enter the full path and filename for the LLCE characterization database file that was generated for this LLCE retrieval. In addition the user is required to enter the full path and filename for the FRRDS generated gamma assay data file. Standard Windows file dialog boxes will assist the user in locating and selecting these files. The program will verify that the LLCE drawing number, tank farm, and tank number matches the information recorded in the LLCE characterization database file. In addition the program will verify that the entered LLCE retrieval date matches the dates in the FRRDS generated gamma assay data file. If there is a mismatch the program user will have the option of quitting the program, selecting another LLCE characterization database file, selecting another FRRDS data file, or selecting 


\section{WHC-SD-WM-CSWD-080 Rev.0}

another LLCE. To exit this window the user can select next or ok. Selecting next opens the field data input window. Selecting ok takes you back to the main window.

3.2.1.2.3 Field data window - This window is opened when the program user selects the menu command Eield Data. The user is required to enter the arbitrary crane position in thousands of a feet when the LLCE mounting flange is visible in the video view window on the LLCE flexible receiver assembly. There is also an entry on this screen for the LLCE retrieved weight, weight of the flexible receiver bag, and the weight of the lifting dunnage that will remain inside the flexible receiver bag. The user can enter either the weight for each component or a gross weight for all three. To exit this window the user selects calculate or ok. Selecting calculate will initiate the Calculate menu command which will start the characterization analysis for the LLCE. Selecting ok will take the program user back to the main program window.

3.2.1.2.4 Add Data window - This window is opened when the program user selects the $A d d$ Data menu command. Normally this command is inactive. It becomes active only if during characterization analysis (Calculate menu command) gaps are found in the FRRDS gamma assay data. If gaps are found in the gamma assay data the characterization analysis will stop and this data window will open. The program user will be prompted to add the missing gamma radionulide content data for the one foot section(s) that are missing data. To exit this window the user selects calculate or ok. Selecting calculate will initiate the Calculate menu command which will start the characterization analysis for the LLCE. Selecting ok will take the program user back to the main program window.

3.2.1.2.5 Calculate Dialog Box - This dialog box is opened when the program user selects the Calculate menu command. Current status of analysis run will be displayed in this box. This box will close when characterization analysis is complete and a dialog box will be displayed which will notify the user that characterization analysis is complete and that analysis was either successful or failed. If the analysis failed the program user will have the option to display the error report for the analysis run. Errors and warnings will be saved in the filename.err file.

3.2.1.2.6 Print select Window - This window is opened when the program user selects the Print menu command under the Eile menu bar. This menu command is inactive until the LLCE select window and field data window input has been completed. Only the LLCE summary report can be printed until characterization analysis has been successfully completed. Each report will have the selected LLCE part and drawing number, tank farm, tank number, tank riser, program user name(s), and 


\section{WHC-SD-WM-CSWD-080 Rev.0}

current time and date print on each report. Also the program user has the option to select printer and to setup printer.

The program will combine the following reports where possible to minimize the amount of hard copy.

The following reports can selected to be printed:

- The LLCE Select Report will print information entered in the LLCE select and field data windo $w$ s

- The LLCE Characterization , nalysis Summary Report will print the summary results of the characterization analysis run as specified in section 2.3.3.

- The FRRDS Gamma Assay Summary Report will print out for each one foot section of the selected LLCE : the measured gamma assay content, the geometry correction factors applied, and the geometry corrected gamma assay content. The total measured gamma radionuclide inventory will be summed and printed at the end of the report. If the tank waste layer has more than one layer then subtotals for each layer will be printed.

- The Calculated Radionuclide/Chemical Content report will print out the table showing the calculated total radionuclide and chemical content for the selected LLCE. The percent of waste for each component will be reported in this table. If the tank waste layer has more than one layer then subtotals for each layer will be printed.

The hard copy report will list any fission/activation nuclides that exceed one percent of the weight of the waste. If there are less than three radionuclides that exceed one percent, then the radionuclides with the highest concentration will be reported. At least three radionuclides will be reported.

The hard copy report will list any TRU/Fissile nuclides that exceed one percent of the weight of the waste. If there are less than three radionuclides that exceed one percent, then the radionuclides with the highest concentration will be reported. At least three radionuclides will be reported. 


\section{WHC-SD-WM-CSWD-080 Rev.0}

- The LLW Calculations Summary report will print out the table that shows the sum of fractions for Category 1 and Category 3 LLW, and NRC Class C. The report will print recommended LLW characterization from these results. Categories can be Category 1 LLMW, Category 3 LLMW, greater than Category 3 LLMW, greater than Class C.

Note it is possible that some LLCE may be characterized as Low Level Waste (LLW). The program will always assume the LLCE is mixed waste in it's printed reports.

- The TRU Calculations Summary report will print out the table that shows the sum of fractions for TRU isotopes. The report will print at bottom of report if LLCE waste package is TRU or suspect TRU based on this sum. Categories can be TRU or suspect TRU.

- The CWC LLW Storage Noncombustible Limits report will print out the table that shows the sum of fractions for the Category 3 noncombustible waste limits. This is valid if LLCE waste package is stored at the Central Waste Complex (CWC). It is assumed that LLCE waste packages going into storage will be considered noncombustible.

- The PE-Ci Report for TRU Waste report will print out the table used to calculate the Plutorium Equivalent Curie (PE-Ci) for the LLCE waste package. This is only valid for TRU waste. The report will flag if the $35 \mathrm{PE}-\mathrm{Ci}$ limit for TRU waste packages is exceeded.

- The Fissile Gram Equivalent For TRU Waste report will print out the table used to calculate the Fissile Gram Equivalent (FGE) content for the LLCE waste package. This is only valid for TRU waste.

- The Alpha Content For TRUWaste report will print out the table used to calculate the alpha content of the LLCE waste package. This is only valid for TRU waste.

- The Accountable Materials report will print out the table used to determine if the LLCE waste package contains accountable materials. If accountable materials are present the program user will be reminded that a DOE/NRC Form 741 is required.

- The Heat Generation report will print out the table used to determine the heat generation in the LLCE waste package. The report will report if the 


\section{WHC-SD-WM-CSWD-080 Rev.0}

LLCE waste package exceeds a $3.5 \mathrm{~W} / \mathrm{m}^{3}\left(0.1 \mathrm{~W} / \mathrm{ft}^{3)}\right.$ heat generation rate.

- The Transportation Category report will print out the table use to determine the transportation category for the LLCE waste package. Transportation categories can be LSA, Limited Quantity, Type A, Type $B$, and HRC.

- The CWC Type A Category report will print out the table used to determine if the LLCE waste package would be categorized as a Type A waste package using the CWC package limits and $A 2$ values found in WHC-EP-0063-4, Appendix L.

- The CWC Dose Equivalent Curie (DE-Ci) report will print out the table used to calculate the CWC DE-Ci content of the LLCE waste package. This is only valid if the CWC Type A Category report limits are exceeded.

- The LLCE U-235 Content report will report the ${ }^{235} \mathrm{U}$ content of the LLCE waste package. If this exceeds 15 grams the program user will be reminded that a criticality safety analysis is required.

- The SARP LIMITS report will print the table used to determine if any LLCE waste packaging SARP limits have been exceeded. If limits are exceeded the report will indicate which limits have been exceeded and by how much.

- The Hazardous Waste Designation report will print the recommended hazardous waste codes for the LLCE waste package. Designation logic will be printed.

- The Error Report - will print errors and warning generated during characterization analysis.

\subsection{OTHER REQUIREMENTS}

\subsubsection{Operations}

The LLCE characterization database program is not intended for field use. The LLCE waste characterization analysis program can be used in the field or in the office after LLCE retrieval. Some of the information required by the LLCE waste characterization analysis 


\section{WHC-SD-WM-CSWD-080 Rev.0}

program must be recorded in the field at the time of LLCE retrieval. The crane position reading at the point where the LLCE mounting flange is visible in the flexible receiver video view window must be recorded. Also if the retrieved LLCE, flexible receiver bag, and lifting dunnage weights are measured in the field, this information is required by the LLCE waste characterization analysis program. If the LLCE waste characterization analysis program is used during LLCE retrieval this information can be entered directly into the program at the time the field information is recorded.

\subsubsection{Reliability and Recovery}

Error detection, error handling, and recovery was discussed in section 3.1.1.4 of this plan. Data files generated by these programs should be backed up by the program user to prevent data loss.

\subsubsection{Audit}

All printed reports will indicate data file name and date so computer data files can be matched with hard copy reports. All input data can be printed in hard copy reports to allow for checking of input data. In addition an audit file will be maintained which will track use of the characterization database program.

\subsubsection{Testing and Acceptance Criteria}

A document will be written to perform the acceptance test according to the requirements of WHC-CM-3-10 for the software developed under this plan.

\subsubsection{Documentation}

A user's manual shall be written in FY97 for the programs developed under this plan.

\subsubsection{Training}

The user's manual for this program will give a tutorial on use of the programs. Completion of the tutorial in the manual should provide adequate trairing for user of the software.

\subsection{SCHEDULE}

The schedule for this software development effort is shown in Appendix D. Software development is to be complete by $9 / 30 / 96$. 


\section{WHC-SD-WM-CSWD-080 Rev.0}

\subsection{REFERENCES}

Roach, H. L., 1995, Disposal of Tank Farm Long-Length Contaminated Equipment: Radiological and Chemical Characterization Plan, Rev. 0, Westinghouse Hanford Company, Richland Washington.

WAC 173-303, 1993, "Dangerous Waste Regulations," Washington Administrative Code, as amended.

Resource Conservation and Recovery Act of 1976, 42 U.S.C. 6901, et seq.

Titzler, P. A., 1993, Disposal of Tank Farm Long-Length Contaminated Equipment: Alternative Options Study and Engineering Support Information, WHC-SD-WM-ES-265, Rev. 0-A, Westinghouse Hanford Company, Richland, Washington.

Willis, N. P., Hanford Solid Waste Acceptance Criteria, WHC-EP-0063-4, Westinghouse Hanford Company, Richland, Washington.

WHC Traffic Group, Hazardous Materials Packaging \& Shipping, WHC-CM-2-14, Westinghouse Hanford Company, Richland, Washington.

Software Practices, WHC-CM-3-10, Westinghouse Hanford Company, Richland, Washington.

Twins User Guide, Tank Waste Information Network system Version 4.0, PNL-8824-2, Pacific Northwest Laboratory, Richland, Washington.

Serier, M. N., Material Control and Accountability Plan, WHC-IP-1019, Rev. 0, Westinghouse Hanford Company, Richland, Washington.

Troyer, G. L., Project W15I Flexible Receiver Radiation Detector System acceptance Test Report, WHC-SD-W151-ATR-001, Rev. 0, Westinghouse Hanford Company, Richland, Washington.

Killian, Wayne E., 1992, Operator's Guide for VAXGAP, a Gamma-Ray Spectrum Analysis Package, EGG-2672, Idaho National Engineering Laboratory, Idaho Falls, Idaho.

Killian, Wayne E., 1992, Operator's Guide for the Hanford Spectrometer System, RMLB7A0-92-002, Idaho National Engineering Laboratory, Idaho Fals, Idaho.

Tedeschi, David J., 1994, Specification for Gamma Assay, WHC-V-W320-0001, Rev. 0, Westinghouse Hanford Company, Richland, Washington. 


\section{WHC-SD-WM-CSWD-080 Rev.0}

Dowell, Jack L., 1993, Project W-151 Flexible Receiver Radiation Detector System Acceptance Test Report, WHC-SD-W151-ATR-001, Rev 0, Westinghouse Hanford Company, Richland, Washington. 
WHC-SD-WM-CSWD-080 Rev.0

APPENDIX A - DATABASE FILE DESCRIPTION AND STRUCTURE

A-1 


\section{WHC-SD-WM-CSWD-080 Rev.0}

\subsection{DATABASE FORMAT}

This appendix describes the format of the databases maintained by the LLCE characterization database program. All databases will be in Microsoft Access 2.0 format but will be directly accessed, viewed, and edited by the LLCE characterization database program.

Terminology

Type - Type of data entered into Field

A - Alphanumeric any letter or number allowed up to field length

S - Short Integer number $(-32,767$ to 32,767$)$

$\mathrm{N}$ - Number entry with 15 significant digits $\left(10^{-307}\right.$ to $\left.10^{+308}\right)$

D - Date entry $(\mathrm{mm} / \mathrm{dd} / \mathrm{yy})$

$\mathrm{M}$ - Memo field

Size - $\quad$ Size of field. N/A means the size is preset by data type

Index Key - Index (Sort order) for database. Determine which fields and order for sorting of database

\subsection{Tank Waste Characterization Data}

The database file name is TANKCHAR.DB. Fields defined in this database are as follows:

\begin{tabular}{|c|c|c|c|c|}
\hline \multicolumn{5}{|c|}{ TANKCHAR.DB } \\
\hline \hline$\#$ & Field Name & Type & Size & Index Key \\
\hline \hline 1 & Tank Farm & A & 2 & 1 \\
\hline $2^{-}$ & Tank Number & S & N/A & $2^{-}$ \\
\hline 3 & Constituent & A & 25 & 3 \\
\hline 4 & CAS & A & 14 & 4 \\
\hline 7 & Unit Mass & A & 2 & \\
\hline 8 & Unit Volume & A & 2 & \\
\hline 9 & Layer Content & N & N/A & \\
\hline 10 & Layer Number & S & N/A & \\
\hline
\end{tabular}


WHC-SD-WM-CSWD-080 Rev.0

\begin{tabular}{|c|c|c|c|c|}
\hline \multicolumn{5}{|c|}{ TANKCHAR.DB } \\
\hline \hline$\#$ & Field Name & Type & Size & Index Key \\
\hline 10 & Layer Number & S & N/A & \\
\hline 11 & Layer Thickness & N & N/A & \\
\hline 12 & SpG Layer & N & N/A & \\
\hline 37 & Time & A & 12 & \\
\hline 38 & Date & D & N/A & \\
\hline
\end{tabular}

Field Notes:

a) Tank Farm and Tank Number is the location where this data applies.

a) Constituent for radionuclides is the one or two letter abbreviation for the element name. CAS for radionuclides is the isotope number. For Chemicals constituent is the proper chemical name and CAS is the Chemical Abstract Name for the chemical.

b) Unit Mass is $\mathrm{kg}$ or Curies. All user entries in other units are converted to these units

c) Unit Volume is in $\mathrm{m}^{3}$. If blank content of constituent is defined in terms of total content for waste layer. All user volumes entries in other units are converted to $\mathrm{m}^{3}$.

d) Layer Content is the layer content for the specified constituent in the unit mass and volume for layer.

e) Laver Number is the tank waste layer number (1-10) for this constituent.

f) Layer Thickness is the Layer thickness in meters for layer.

g) SpG Layer is the specific gravity for waste layer.

h) Edit time and date is the last time and date this record was updated. 
WHC-SD-WM-CSWD-080 Rev.0

\subsection{LLCE Physical Data and Description}

This database filename is LLCEPHYS.DB. Fields defined in this database are as follows:

\begin{tabular}{|c|c|c|c|c|}
\hline \multicolumn{5}{|c|}{ LLCEPHYS.DB } \\
\hline \hline$\#$ & Field Name & Type & Size & Index Key \\
\hline 1 & LLCE Description & A & 50 & \\
\hline 2 & Max Diameter & N & N/A & \\
\hline 3 & Max Tip to Tip Length & N & N/A & \\
\hline 4 & Flange to Tip Length & N & N/A & \\
\hline 5 & LLCE Weight & N & N/A & \\
\hline 6 & Drawing list & A & 45 & 3 \\
\hline 7 & Drawing Number & N & N/A & 1 \\
\hline 8 & Part Number & A & 6 & 2 \\
\hline 9 & Farms & A & 30 & \\
\hline 10 & Waste Container Size & S & N/A & \\
\hline 11 & Comment & A & 240 & \\
\hline 12 & Time & A & 12 & \\
\hline 13 & Date & D & N/A & \\
\hline
\end{tabular}

Field Notes:

a) LLCE Description is the descriptive name of the LLCE.

b) Max Diameter is the maximum circular diameter of the LLCE with the center of this circle located at the midpoint between the lift points. All entries are converted to meters. If this entry is zero the maximum diameter has not been defined or requires field verification.

c) Max tip to tip length is the distance from the uppermost tip to the bottom tip of the LLCE (Max Length). All entries are converted to meters. If this entry is zero this 


\section{WHC-SD-WM-CSWD-080 Rev.0}

length can not be defined using assembly drawing. Other sources of information must be found to determine this length.

d) Elange to tip length is the distance from the bottom surface of the LLCE mounting flange to bottom tip of the LLCE. All entries are converted to meters. If this entry is zero this length must be determined in the field or from sources other than the assembly drawing. Many of these LLCE are adjustable so this length is determined at installation.

e) LLCE weight is the current dry clean weight of the LLCE. All entries are converted to $\mathrm{kg}$.

f) Drawing List is complete drawing number(s) for the LLCE. There may be more than one drawing number listed here. The primary assembly drawing should be the first number entered. This number typically starts with a "H-2" prefix. This will not be true for vendor only drawings.

g) Drawing number is the number part for the primary assembly drawing for this LLCE. For a typical H-2-XXXXXX Hanford drawing this is the "XXXXXX" number part of the drawing number. For vendor only drawings this will be recorded as zero to let the program know that the key will be on the drawing list field.

h) Part number is the part number on drawing number for this LLCE. Some drawings have more than one LLCE defined. If this entry is zero there are part numbers specified for the LLCE in the assembly drawing(s). Note that several LLCE with different. lengths and diameters may share the same part and drawing number.

I) Earms are the tank farms this LLCE was designed for. Typically this is from the title block on the LLCE assembly drawing. Specific tanks may also be specified.

j) Waste Container Size is the LLCE waste container size this LLCE fits in. This will be a number between 1 and 8 .

k) Comment allows a short comment to be entered for the LLCE.

1) Time and Date is the time and date the data for this LLCE was last changed.

\subsection{LLCE Geometry Correction Factors}

This database filename is LLCEGEOM.DB. Fields defined in this database are as follows: 
WHC-SD-WM-CSWD-080 Rev.0

\begin{tabular}{|c|c|c|c|c|}
\hline \multicolumn{5}{|c|}{ LLCEGEOM.DB } \\
\hline \hline \# & Field Name & Type & Size & Index Key \\
\hline 1 & Drawing List & $\mathrm{A}$ & 45 & \\
\hline 2 & Drawing Number & $\mathrm{N}$ & N/A & 1 \\
\hline 3 & Part Number & $\mathrm{A}$ & 6 & \\
\hline 4 & Start Location & $\mathrm{N}$ & $\mathrm{N} / \mathrm{A}$ & 2 \\
\hline 5 & Gamma Isotope Element & $\mathrm{A}$ & 4 & 3 \\
\hline 6 & Gamma Isotope Number & $\mathrm{S}$ & N/A & 4 \\
\hline 7 & Correction Factor \#1 & $\mathrm{N}$ & N/A & \\
\hline 8 & Correction Factor \#2 & $\mathrm{N}$ & N/A & \\
\hline 9 & Correction Factor \#3 & N & N/A & \\
\hline 10 & Time & A & 12 & \\
\hline 11 & Date & D & N/A & \\
\hline
\end{tabular}

Field Notes:

a) Drawing List, Drawing Number, and Part Number are as explained in section 1.2 in this appendix.

b) Start Location is the distance (m) from the bottom tip of the LLCE to the point on the LLCE where the geometry correction factor is first applied. This geometry factor is applicable to the section of the LLCE between the current start location and the start location of the next data record. If there is no next data record the correction factor applies from the current start location to the bottom flange of the LLCE.

c) Gamma Isotope Element is the two letter abbreviation for the element name for which the geometry correction factor is defined. If this is a metastable element enter the letter ' $\mathrm{m}$ ' before the element name. For example the element ${ }^{137 \mathrm{~m}} \mathrm{Cs}$ would be entered as "mCs".

d) Gamma Isotope Number is the isotope number for the gamma isotope element. 


\section{WHC-SD-WM-CSWD-080 Rev.0}

e) Correction Factor \#1 is the geometry correction factor for detector \#1 that is used to correct the FRRDS measured gamma isotope content numbers for geometry of the LLCE. Correction Factor $\# 2$ and $\# 3$ are the correction factors for detector $\# 2$ and detector \#3.

f) Time and date is the time and date this record was last changed.

\subsection{LLCE Waste Container Data}

The name of this database is LLCECONT.DB. Fields defined in this database are as follows:

\begin{tabular}{|c|c|c|c|c|}
\hline \hline \multicolumn{5}{|c|}{ LLCECONT.DB } \\
\hline \hline$\#$ & Field Name & Type & Size & Index Key \\
\hline 1 & Container Number & S & N/A & 1 \\
\hline 2 & Container OD & N & N/A & \\
\hline 3 & Container ID & N & N/A & \\
\hline 4 & Container Length & N & N/A & \\
\hline 5 & Max LLCE Diameter & N & N/A & \\
\hline 6 & Max LLCE Length & N & N/A & \\
\hline 7 & Tare Weight & N & N/A & \\
\hline 8 & Container Internal Volume & N & N/A & \\
\hline 9 & Container External Volume & N & N/A & \\
\hline 10 & Container Drawing Number & A & 30 & \\
\hline 11 & Skid Drawing Number & A & 30 & \\
\hline 12 & Skid Weight & N & N/A & \\
\hline 13 & Time & A & 12 & \\
\hline 14 & Date & D & N/A & \\
\hline
\end{tabular}




\section{WHC-SD-WM-CSWD-080 Rev.0}

Field Notes:

a) Container number is a number 1 through 8 representing the 8 LLCE waste containers.

b) Container $O D$ is the outside diameter of the container in meters.

c) Container ID is the inside diameter of the container in meters.

d) Max LLCE diameter is the maximum diameter, in meters, for any LLCE that will fit in this container.

e) Max LLCE length is the maximum tip to tip length, in meters, for any LLCE that will fit in this container.

f) Tare weight is the empty weight of the container in $\mathrm{kg}$.

g) Container internal volume is the internal volume of the container in $\mathrm{m}^{3}$.

h) Container external volume is the external volume of the container in $\mathrm{m}^{3}$. This volume is equal to the container length times height.

I) Container drawing number is the "H-2" drawing number for the top assembly for this container.

j) Skid drawing number is the "H-2" drawing number for the top assembly of the skid that fits inside this container.

k) Skid weight is the weight of the skid in $\mathrm{kg}$.

1) Time and date it the time and date the data for this container was last changed.

\subsection{Radionuclide Physical Constants}

The name of this database is LLCENUC.DB. Fields defined in this database are as follows:

\begin{tabular}{|c|c|c|c|c|}
\hline \multicolumn{4}{|c|}{ LLCENUC.DB } \\
\hline \hline$\#$ & Field Name & Type & Size & Index Key \\
\hline 1 & Element Isotope & S & N/A & 2 \\
\hline
\end{tabular}




\section{WHC-SD-WM-CSWD-080 Rev.0}

\begin{tabular}{|c|c|c|c|c|}
\hline \multicolumn{5}{|c|}{ LLCENUC.DB } \\
\hline \hline$\#$ & Field Name & Type & Size & Index Key \\
\hline 2 & Element Name & A & 8 & 1 \\
\hline 3 & Specific Activity & N & N/A & \\
\hline 4 & Half Life & N & N/A & \\
\hline 5 & Heat Generation Rate & N & N/A & \\
\hline 6 & Daughter 1 & S & 7 & \\
\hline 7 & Branching Ratio & N & N/A & \\
\hline 8 & Daughter 2 & S & 7 & \\
\hline 9 & Branching Ratio & N & N/A & \\
\hline 10 & Alpha Emitter & S & N/A & \\
\hline 11 & Beta Emitter & S & N/A & \\
\hline 12 & Gamma Emitter & S & N/A & \\
\hline 13 & Fissile Material & S & N/A & \\
\hline 14 & Hanford TRU Isotope & S & N/A & \\
\hline 15 & NRC TRU Isotope & S & N/A & \\
\hline 16 & Time & A & 12 & \\
\hline 17 & Date & D & N/A & \\
\hline & & & & \\
\hline & & & & \\
\hline
\end{tabular}

Field Notes:

a) Element Isotope is the isotope number for this radionuclide

b) Element Name is the two letter abbreviation for the element name for the radionuclide. If this is a metastable element enter the letter ' $m$ ' before the element name. For example the element ${ }^{137 m} \mathrm{Cs}$ would be entered as " $\mathrm{mCs}$ ".

c) Specific Activity is the number of curies in one gram of the radionuclide $(\mathrm{Ci} / \mathrm{g})$.

d) Half Life is the time for cne half of the radionuclide to decay in years. 


\section{WHC-SD-WM-CSWD-080 Rev.0}

e) Heat Generation Rate is the heat generated by radioactive decay of the radionuclide in watts per cubic meter $\left(\mathrm{w} / \mathrm{m}^{3}\right)$.

f) Daughter 1 is the name of the daughter radionuclide (i.e. ${ }^{137 \mathrm{~m}} \mathrm{Ba}$ or $137 \mathrm{~m}-\mathrm{Ba}$ ). Daughter 1 Ratio is the branching ratio from the parent radionuclide. Daughter 2 is the name of a second daughter product from the decay of the parent radionuclide. Daughter 2 Ratio is the branching ratio for this second radionuclide.

g) Alpha Emitter will indicate if this radionuclide emits an alpha particle when it decays (1 for true and 0 for false).

h) Beta Emitter will indicate if this radionuclide emits a beta particle when it decays (1 for true and 0 for false).

I) Gamma Emitter will indicate if this radionuclide emits gamma radiation when it decays ( 1 for true and 0 for false).

j) Eissile Material will indicate if this radionuclide is a fissile material as specified in WHC-EP-0063-4, latest revision ( 1 for true and 0 for false).

k) Hanford TRU Isotope will indicate if this radionuclide is a transuranic (TRU) radionuclide as specified in WHC-EP-0063-4, latest revision ( 1 for true and 0 for false).

1) NRC TRU Isotope will indicate if this radionuclide is a transuranic (TRU) radionuclide by NRC definition as specified in WHC-EP-0063-4, latest revision ( 1 for true and 0 for false). NRC specifies all alpha emitting nuclides with half lives greater than 5 years.

m) Time and Date is the time and date this record was last changed.

\subsection{Radionuclide Regulatory Data}

The name of this database is RADREG.DB. Fields defined in this database are as follows:

\begin{tabular}{|c|c|c|c|c|}
\hline \multicolumn{3}{|c|}{ RADREG.DB } \\
\hline \hline$\#$ & Field Name & Type & Size & Index Key \\
\hline \hline 1 & Element Isotope & $\mathrm{S}$ & N/A & 2 \\
\hline 2 & Element Name & $\mathrm{A}$ & 8 & 1 \\
\hline
\end{tabular}


WHC-SD-WM-CSWD-080 Rev.0

\begin{tabular}{|c|c|c|c|c|}
\hline \multicolumn{5}{|c|}{ RADREG.DB } \\
\hline \hline$\#$ & Field Name & Type & Size & Index Key \\
\hline \hline 3 & Category 1 LLW Limit & N & N/A & \\
\hline 4 & Category 3 LLW Limit & N & N/A & \\
\hline 5 & NRC Class C Limit & N & N/A & \\
\hline 6 & Noncombustible Waste Limit & N & N/A & \\
\hline 7 & PE-Ci Correction Factor & N & N/A & \\
\hline 8 & Pu-239 FGE Correction Factor & N & N/A & \\
\hline 9 & DOT A2 Limit & N & N/A & \\
\hline 10 & EP-0063 A2 Limit & N & N/A & \\
\hline 11 & CWC Curie Limit per Package & N & N/A & \\
\hline 12 & DE-Ci Curie Factor & N & N/A & \\
\hline 13 & Current SARP Limits & N & N/A & \\
\hline 14 & 741 Reporting Unit & N & N/A & \\
\hline 15 & Time & A & 12 &. \\
\hline 16 & Date & N & N/A & \\
\hline
\end{tabular}

Field Notes:

a) Element Isotope is the isotope number for this radionuclide

b) Element Name is the two letter abbreviation for the element name for the radionuclide. If this is a metastable element enter the letter ' $\mathrm{m}$ ' before the element name. For example the element ${ }^{137 m} \mathrm{Cs}$ would be entered as "mCs".

c) Category 1 LLW Limit is the limit for a waste package for the radionuclide in curies for Category 1 Low Level Waste Disposal. The limits will be as specified in WHC-EP0063-4, latest revision. 


\section{WHC-SD-WM-CSWD-080 Rev.0}

d) Category 3 LLW Limit is the limit for a waste package for the radionuclide in curies for Category 3 Low Level Waste Disposal. The limits will be as specified in WHC-EP0063-4, latest revision.

e) NRC Class C Limit is the limit for a waste package for the radionuclide in curies for Category 3 Low Level Waste Disposal. The limits will be as specified in WHC-EP$0063-4$, latest revision. Units are in $\mathrm{Ci} / \mathrm{m}^{3}$ except for ${ }^{24} \mathrm{Pu}$ and ${ }^{242} \mathrm{Cm}$ where the units are in $\mathrm{nCi} / \mathrm{g}$.

f) Cat 3 Nocomb. Limit is the limit for a waste package for the radionuclide in curies for Category 3 Low Level Waste Disposal of a noncombustable waste package. The limits will be as specified in WHC-EP-0063-4, latest revision.

g) PE-Ci Correction Factor is the multiplication factor applied to selected radionuclides to calculate the equivalent ${ }^{239} \mathrm{Pu}$ content of a waste package. The limits .will be as specified in WHC-EP-0063-4, latest revision.

h) $\mathrm{Pu}$-239 FGE Factor is the multiplication factor applied to selected radionuclides to calculate the equivalent ${ }^{239} \mathrm{Pu}$ fissile gram equivalent content of a waste package. The limits will be as specified in WHC-EP-0063-4, latest revision.

I) DOT A2 Limit is the limit for a waste package for the radionuclide in curies for a TypeA waste package. The limits will be as specified in the current DOT 49 CFR 173.

j) EP-0063 A2 Limit is the limit for a waste package for the radionuclide in curies for a Type-A waste package. The limits will be as specified in the current WHC-0063-4, Appendix $\mathbf{L}$.

k) CWC Limit per Package is the limit for a waste package for selected radionuclides in curies for a Type-A waste package. The limits will be as specified in WHC-EP-0063-4, latest revision.

1) DE-Ci Curie Factor is the multiplication factor applied to selected radionuclides to calculate the Dose Equivalency Curies (DE-Ci) in a waste package. The limits will be as specified in WHC-EP-0063-4, latest revision.

m) Current SARP Limits is the curie limit for the radionuclide as established in the SARP for the waste package.

n) 741 Reporting Unit limits for radionuclides in grams. The limits will be as specified in WHC-IP-1019, Material Control and Accountability Plan. 


$$
\text { WHC-SD-WM-CSWD-080 Rev.0 }
$$

o) Time and Date is the time and date this record was last changed.

\subsection{Chemical Regulatory Data}

The name of this database is CHEMREG.DB. Fields defined in this database are as follows:

\begin{tabular}{|c|c|c|c|c|}
\hline \multicolumn{5}{|c|}{ CHEMREG.DB } \\
\hline$\#$ & Field Name & Type & Size & Index Key \\
\hline 1 & Constituent Name & A & 30 & 2 \\
\hline 2 & CAS \# & A & 12 & 1 \\
\hline 3 & D Code & A & 4 & \\
\hline 4 & D Code Limit & $\mathrm{N}$ & N/A & \\
\hline 5 & Time & A & 12 & \\
\hline 6 & Date & $\mathrm{D}$ & N/A & \\
\hline
\end{tabular}

Field Notes:

a) Constituent Name is the name of the chemical

b) CAS\# is the chemical abstract number for the chemical.

c) D Code is the ' $D$ ' code number that applies to chemicals that are heavy metals.

d) D Code Limit is the limit a ' $\mathrm{D}$ ' listed chemical in $\mathrm{mg} / \mathrm{L}$. This will taken from WAC 173-303-090(8)(C).

e) Time and Date is the time and date this record was last changed.

\subsection{LLCE Setup}

The name of this database is LLCESET.DB. This database saves the list of valid measured gamma radionuclides. The structure of this database is as follows: 
WHC-SD-WM-CSWD-080 Rev.0

\begin{tabular}{|c|c|c|c|c|}
\hline \multicolumn{4}{|c|}{ LLCESET.DB } \\
\hline \hline$\#$ & Field Name & Type & Size & Index Key \\
\hline 1 & Element Isotope & S & N/A & 1 \\
\hline 2 & Element Name & A & 8 & 2 \\
\hline 3 & Time & A & 12 & \\
\hline 4 & Date & D & N/A & \\
\hline
\end{tabular}

Field Notes:

a) Element Isotope is the isotope number for this valid gamma radionuclide

b) Element Name is the two letter abbreviation for the element name for the valid gamma radionuclide. If this is a metastable element enter the letter ' $m$ ' before the element name. For example the element ${ }^{137 \mathrm{~m}} \mathrm{Cs}$ would be entered as " $\mathrm{mCs}$ ".

c) Time and Date is the time and date this record was last changed.

\subsection{Audit File Format}

The name of this database is LLCEAUD.DB. This database saves information for the use of the LLCE Characterization database program. The structure of this database is as follows:

\begin{tabular}{|c|c|c|c||c|}
\hline \multicolumn{5}{|c|}{ LLCEAUD.DB } \\
\hline \hline$\#$ & Field Name & Type & Size & Index Key \\
\hline 1 & User Name & A & 30 & \\
\hline 2 & Char Data File Name & A & 42 & \\
\hline 3 & LLCE Description & A & 50 & \\
\hline 4 & LLCE Drawing Number & N & N/A & \\
\hline 5 & LLCE Part Number & A & 6 & \\
\hline 6 & Waste Tank & A & 8 & \\
\hline
\end{tabular}


WHC-SD-WM-CSWD-080 Rev.0

\begin{tabular}{|c|c|c|c|c|}
\hline \multicolumn{5}{|c|}{ LLCEAUD.DB } \\
\hline \hline$\#$ & Field Name & Type & Size & Index Key \\
\hline 7 & Tank Riser & A & 6 & \\
\hline 8 & TANKCHAR.DB Date & D & N/A & \\
\hline 9 & LLCEPHYS.DB Date & D & N/A & \\
\hline 10 & LLCEGEOM.DB Date & D & N/A & \\
\hline 11 & LLCECONT.DB Date & D & N/A & \\
\hline 12 & LLCENUC.DB Date & D & N/A & \\
\hline 13 & RADREG.DB Date & D & N/A & \\
\hline 14 & CHEMREG.DB Date & D & N/A & \\
\hline 15 & LLCESET.DB Date & D & N/A & \\
\hline 16 & Time & A & 12 & 2 \\
\hline 17 & Date & D & N/A & 1 \\
\hline
\end{tabular}

Field Notes:

Field Notes:

a) User Name is the user name entered by the program user.

b) Char Data File Name is the name selected by the program user to save user input and the LLCE characterization database file used by the LLCE characterization analysis program.

c) LLCE Description is the description of the selected LLCE as entered into the LLCEPHYS.DB database.

d) LLCE Drawing Number is the drawing number of the selected LLCE as entered into the LLCEPHYS.DB database.

e) LLCE Part Number is the part number of the selected LLCE as entered into the LLCEPHYS.DB database. 


\section{WHC-SD-WM-CSWD-080 Rev.0}

f) Waste Tank and Tank Riser are the waste tank and tank riser selected by the program user for LLCE retrieval.

g) TANKCHAR.DB Date. LLCEPHYS.DB Date, LLCEGEOM.DB Date, LLCECONT. DB Date. LLCENUC.DB Date, RADREG.DB Date, CHEMREG.DB Date, and LLCESET.DB Date are the dates these databases were last changed.

\subsection{Database File Generated for LLCE Retrieval}

This file will not be in Microsoft Access 2.0 format. It will be a binary file generated by the LLCE characterization database program containing the data that pertains to the LLCE being retrieved. This is the database file required by the LLCE waste characterization analysis program. This file will consist of data from all eight databases maintained by the characterization database program.

LLCE data will be extracted from the LLCEPHYS.DB database for the LLCE that is being retrieved. Geometry correction factors for the LLCE will be retrieved from LLCEGEOM.DB. Tank waste characterization data, for the waste tank the LLCE is being retrieved from, will be extracted from ${ }^{2} \mathrm{ANKCHAR.DB}$. The waste container physical data will be extracted from the LLCECONT.DB. Physical constants for the radionuclides present in the tank waste characterization information will be extracted from LLCENUC.DB. Regulatory data for the radionuclides and chemicals listed in the tank waste characterization data will be extracted from RADREG.DB and CHEMREG.DB. LLCE suspect TRU limit, the list of gamma radionuclides to be measured by the FRRDS system will be read from LLCESET.DB.

All of the extracted data will be saved to the file name selected by the program user when the LLCE characterization database program was started. This file can be copied and transferred to the computer running the LLCE waste characterization analysis program via a floppy disk. 
WHC-SD-WM-CSWD-080 Rev.0

APPENDIX B - DESCRIPTION OF EXISTING FRRDS SOFTWARE 


\section{WHC-SD-WM-CSWD-080 Rev.0}

\subsection{SYSTEM DESCRIPTION}

The Flexible Receiver Radiation Detector System (FRRDS) was designed as part of project W-151, Tank 101-AZ Waste Retrieval System. It's purpose is to provide a remote and automated method of identifying gamma-ray emitting radioisotopes in the waste remaining on an LLCE.

The FRRDS uses 3 High Purity Germanium (HPGe) detectors, nuclear instrumentation, a microVAX VAXstation 4000 control computer, a modified amplifier/data multiplexer and control/analysis software. A modified version of the VAXGAP software code is used to preform the control/analysis function.

A description of the existing FRRDS software is as follows:

\section{VAXGAP PROGRAM (Runs on VAX)}

- Command GS starts VAXGAP.

- Command BS;60 starts a repetitive 60 second cycle of data acquisition, analysis of spectra from all three detectors, and saving of resulting data. An additional function of BS command is to create an ASCII file that contains the names of the saved spectrum files. This file is used by the AVR2 program.

- Command ENDBS stops program.

\section{AVR2 PROGRAM (Runs on VAX)}

- AVR2 is a separate program that must be run after data acquisition is complete for an LLCE (the LLCE has been removed and gamma assay is complete). It takes the saved spectrum files ( 3 records for each one foot segment) and computes the concentration values for all nuclides identified. It uses the ASCII file created by VAXGAP with the names of the spectrum files to determine which files to use. The result files (one per foot length) are saved with a .RES file type. There is an ASCII file created that contains summary information for each of the three detectors. This ASCII summary information file is the file that will be used by the LLCE waste characterization analysis program.

Note AVR2 is derived from the original program AVR which averaged the output from all three detectors. Now with different shielding on all three thermocouples averaging is not possible. 


\section{WHC-SD-WM-CSWD-080 Rev.0}

\section{SPREAD PROGRAM (Runs on IBM-PC}

- SPREAD is an WHC produced software code that reads in the ASCII encoded summary results file created by AVR2. This file must be transferred from the VAX to an IBMPC. It reads the summary results file, discards invalid reported gamma radionuclides, and produces a file for each of the three detectors in comma delimited format. These comma delimited files can be read into a spreadsheet program to create a spreadsheet of the results. The LLCE waste characterization analysis program will not use this program.

\subsection{TRANSFER OF FRRDS RESULTS TO IBM-PC}

The VAXstation comes with a MSDOS emulation package that allows MSDOS programs to run on the VAX. To run an MSDOS program you type in SOFTPC at the \$VAX command prompt. All of the files stored in the users current directory will appear under drive letter E: To properly transfer the ASCII coded results files to a floppy disk you must use the command VMS_T0_DOS. The program user must refer to the VAX documentation for more information.

\subsection{FRRDS References}

Killian, Wayne E., 1992, Operator's Guide for VAXGAP, a Gamma-Ray Spectrum Analysis Package, EGG-2672, Idaho National Engineering Laboratory, Idaho Falls, Idaho.

Killian, Wayne E., 1992, Operator's Guide for the Hanford Spectrometer System, RMLB7A0-92-002, Idaho National Engineering Laboratory, Idaho Falls, Idaho.

Tedeschi, David J., 1994, Specification for Gamma Assay, WHC-V-W320-0001, Rev. 0, Westinghouse Hanford Company, Kichland, Washington.

Dowell, Jack L., 1993, Project W-151 Flexible Receiver Radiation Detector System Acceptance Test Report, WHC-SD-W151-ATR-001, Rev 0, Westinghouse Hanford Company, Richland, Washington. 
WHC-SD-WM-CSWD-080 Rev.0

APPENDIX C - FRRDS ASCII ENCODED RESULTS FILE FORMAT 


\section{WHC-SD-WM-CSWD-080 Rev.0}

\subsection{DESCRIPTION}

The Flexible Receiver Radiation Detector System (FRRDS) ASCII encoded results file is produced by the VAX program AVR2. It contains the results from each of the three gamma assay detectors for the LLCE that was retrieved.

There are 10 column of data in this file. The first three lines in the file are the headers for these ten columns as follows:

\begin{tabular}{|l|l|l|l|l|l|l|l|l|l|}
\hline & $\begin{array}{l}\text { Count } \\
\text { Dete }\end{array}$ & $\begin{array}{l}\text { Start } \\
\text { Time }\end{array}$ & $\begin{array}{l}\text { Count } \\
\text { Time }\end{array}$ & Date & Time & $\begin{array}{l}\text { Crane } \\
\text { Position }\end{array}$ & Nuclide & Activity & Error \\
\hline
\end{tabular}

Spectrum - This is the name of the spectrum record for one gamma assay detector. This is a 11 character name assigned by the VAXGAP program. The first 2 characters designate the detector.
A1XXXXXXXXX - designates Detector A 1
A2XXXXXXXXX - designates Detector A2
A3XXXXXXXXX - designates Detector A3

Coun Date - is the date this record was acquired (date LLCE being retrieved).

Start Time - is the time current spectrum count was started.

Count Time - is the number of seconds for counting for this record.

Date - is the date this record was acquired (date LLCE being retrieved).

Time - is the end time for the spectrum count.

Crane Position - is the arbitrary reading of crane position when this record was acquired in thousands of a foot $\left(10^{-3}\right)$.

Nuclide - is the nuclide measured by the detector. There is a two digit number combined with the abbreviation for the element name followed by up to two spaces and the isotope number.

Activity - This is the activity measured for the nuclide in micro curies.

Error - is the VAXGAP report of error in the gamma inventory measurement.

The next line in the file starts the individual spectrum records for the three gamma assay detectors. The first line contains the spectrum, count date, start time, count time, date, time, and crane position. The next line contains the nuclide, activity, and error estimates. There will be one line for each nuclide. When the next line read in contains "A1" , "A2", or "A3" 


\section{WHC-SD-WM-CSWD-080 Rev.0}

as the first two characters in the line, this identifies the beginning of another detector spectrum record. 
WHC-SD-WM-CSWD-080 Rev.0

APPENDIX D - SCHEDULE 


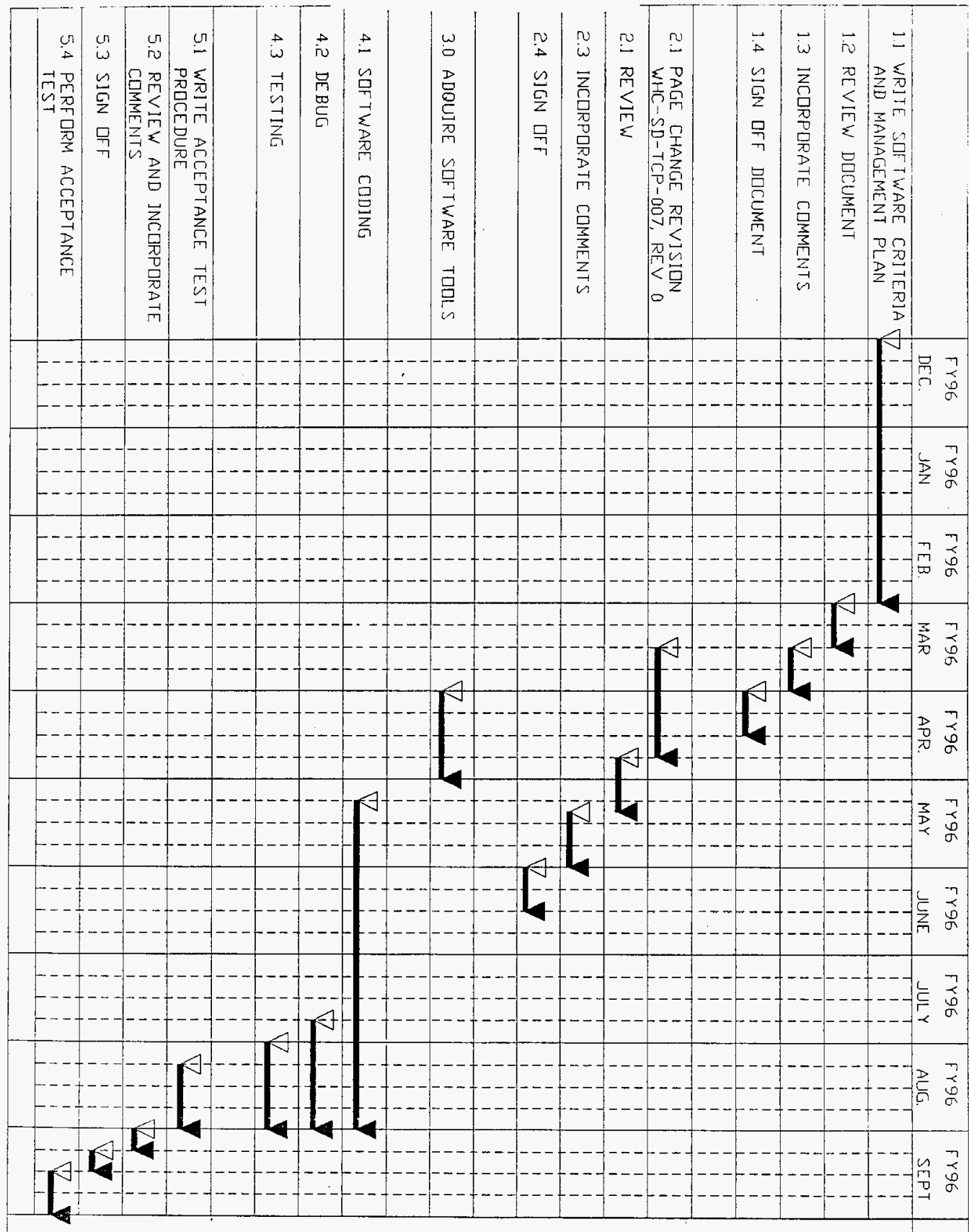


WHC-SD-WM-CSWD-080 Rev.0

SCHEDULE DESCRIPTION

\subsection{SOFTWARE FUNCTIONAL CRITERIA AND MANAGEMENT PLAN}

1.1 Write Software Functional Criteria and Management Plan - Complete software functional criteria and management plan for development of LLCE characterization software.

Start: December 1, 1995

Finish: February 28, 1996

1.2 Review Cycle for Functional Criteria and Management Plan - Review and comments on plan.

Start: February 29, 1996

Finish: March 15, 1996

1.3 Incorporate Comments from Review of Plan - Resolve and incorporate comments into document.

Start: March 18, 1996

Finish: April 1, 1996

1.4 Sign off of Plan - Get signatures and release document.

Start: April 2, 1996

Finish: April 16, 1996

2.0 PAGE REVISION OF LLCE CHARACTERIZATION PLAN WHC-SD-WM-TCP007, REV 0

2.1 Write Page Change Revision - Write page change revision to reflect current LLCE waste characterization plan to reflect current characterization practices.

Start: $3 / 18 / 96$

Finish: 4/23/96

2.2 Review - Review and comment period for revision.

Start: 4/26/96

Finish: 5/10/96 


\section{WHC-SD-WM-CSWD-080 Rev.0}

2.3 Incomorate and disposition comments - Incorporate comments from review.

Start: $5 / 13 / 96$

Finish: 5/27/96

2.4 Sign Off and Release of Revised Document - Get signatures and final release of revised document.

Start: $5 / 28 / 96$

Finish: 6/11/96

3.0 ACQUIRE SOFTWARE TOOLS - Identify and procure necessary software tools to write software.

Start: $4 / 1 / 96$

Finish: 5/1/96

\subsection{SOFTWARE CODING}

4.1 Software Coded - Write software code for programs. Generate databases.

Start: $5 / 13 / 96$

Finish: 9/1/96

4.2 Debug - Debug all modules of software code.

Start: $7 / 10 / 96$

Finish: 9/1/96

4.3 Testing - Test operation of software code (prior to acceptance test).

Start: $8 / 1 / 96$

- Finish: $9 / 1 / 96$

\subsection{ACCEPTANCE TEST PROCEDURE}

5.1 Write Software Acceptance Test Procedure - Write procedure to be used to test software for use.

Start: $8 / 12 / 96$

Finish: 9/2/96 


\section{WHC-SD-WM-CSWD-080 Rev.0}

5.2 Review and Incorporate Comments - Get review and comments on acceptance test procedure. Incorporate comments.

Start: $9 / 3 / 96$

Finish: 9/10/96

5.3 Sign Off - Get signatures and release of acceptance test procedure.

Start: $9 / 11 / 96$

Finish: 9/23/96

5.4 Perform Software Acceptance Test - Perform software acceptance test according to the acceptance test plan.

Start: $9 / 23 / 96$

Finish: 9/30/96 